\title{
Çocuk Hakları ve Uygulama Stratejileri Bağlamında Sokakta Çalıştırılan Çocuklar
}

Fethi GÜNGÖR Yasin ERDURAK ${ }^{2}$

\section{Özet}

Çocuk işçiliği çocukların biyolojik, psikolojik, sosyal ve zihinsel yönden sömürülmesine yol açmakla birlikte çocuk emeğinin en yoğun sömürüldüğü alan sokaklardır. Geniş bir alanı kapsadığı için çocuk açısından diğer çalışma ortamlarından daha fazla tehlike ve riskleri barındıran sokağın denetlenmesi çok daha zordur. Çocuk iş̧̧iliğini genelde insan hakları, özelde ise çocuk hakları bağlamında ele alan bu araştırma, sokakta çalıştırılan çocuklar sorununa odaklanmıştır. Kuramsal yaklaşımlarla ortaya konan sorun sosyal hizmet ekseninde; çocuk hakları, eğitim ve uygulama stratejileri bağlamında değerlendirilmiş ve karar mercilerine yönelik bazı öneriler sunulmuştur.

Anahtar Kelimeler: Çocuk Hakları, Sokakta Çalıştırılan Çocuklar, Sokak Çocukları, Çocuk İşçiliği, Sosyal Hizmet.

\section{Children Working On Street In The Context Of Children's Rights And Implementation Strategy}

\begin{abstract}
Child labour causes exploitation of children in terms of biological, psychological, social and mental. One of the most frequent area for exploitation of child labour is the street. Since it comprises a wide range of environmental hazards and more risks than the other labour field, monitoring and controlling is more difficult. This research focuses on children working on streets and approaches child labour in the context of human rights generally and children rights particularly. The issue is introduced by theoretical approaches, evaluated in the context of children rights, education and implementation strategies as a dimensions of social work and presented some suggestions for decision-makers.
\end{abstract} Social Work.

Keywords: Children Rights, Children Working on Street, Street Children, Child labour,

\section{Giriş}

Sosyal sorun, bir toplumun değerlerine zarar veren ya da o değerleri tehdit eden olaylardır. Türkiye'de artan mültecilik ve terör olayları sosyal sorunlar bağlamında başat hale gelmiştir. Toplumu derinden etkileyen bu sorunlar arasında "çocuk emeğinin sömürülmesi” de önemli bir sosyal sorun olarak öne çıkmıştır.

Geçmişte yalnız ürettiğini tüketen insan, tarım toplumuna geçiş ve hayvanların evcilleştirmesiyle birlikte tükettiğinden fazlasını üretmiş ve bunu diğer mallarla takas etmiştir. Bir süre sonra insanlar, yalnızca malların mallarla değiştirilmeyeceğini anlamış ve birtakım "değişim” araçları ortaya çıkmıştır. Bu değişim araçları başlangıçta değerli taşlar, altın ve gümüş olmuştur. En son değiş̧im aracı olarak ise para kullanılmıştır. Paranın ortaya çıkmasıyla birlikte seri üretime geçilmiş, bunun sonucunda çalışanların ücreti ve gelir dağılımı konuları gündeme gelmiştir. Adaletsiz gelir dağılımı sonucunda ise ucuz işgücü konusu ön plana

\footnotetext{
${ }^{1}$ Doç. Dr., Yalova Üniversitesi, İ̈BF, Sosyal Hizmet Bölümü, fethi.gungor@yalova.edu.tr

2 Arş. Gör., Yalova Üniversitesi, İ̈BF, Sosyal Hizmet Bölümü, yasin.erdurak@yalova.edu.tr
} 
çıkmış, bu işgücünden hem işverenler işgücü maliyetinin az olmasından dolayı hem de aileler hane halkı gelirlerinde artış olduğu için memnun olmuştur. Lakin ucuz işgücünden büyük orandan etkilenen çocuklar olmuştur (Karaman ve Özçalık, 2007: 25-26). Neticede çocuklar, pazarı olmayan ve değer üretmeyen nesne konumuna getirilmiştir (Vassaf, 2013: 158).

Bütün toplumlarda sosyal bir sorun olarak kabul edilen sokakta yaşayan ve sokakta çalıştırılan çocuklar sorunu, olguların ve sorunların tanımlanmasında görüş ayrılıklarına ve farklı yaklaşımlara yol açmaktadır. Sosyal sorunlar, içinde bulunduğu mevcut toplumsal şartlar, hayat tarzı, çalışma kültürü, aile yapısı vb. faktörlere bağlı olarak şekillendiğinden sokakta çalıştırılan ile sokakta yaşayan çocuklara yönelik farklı isimlendirmeler dile getirilmiştir. 1980'li yılların başlarında UNICEF' in ortaya koyduğu "sokaktaki çocuklar" ile "sokağın çocukları" ayrımıyla birlikte, 'sokakta çalışan çocuk kendi isteğiyle mi çalışıyor?' tartışması başlamıştır. Günümüzde ise bu kavramların yerini -çocuk hakları bağlamında yaşanan gelişmeler neticesinde- "sokakta çalıştırılan çocuk" (birtakım etkenlerden kaynaklı sokakta çalıştırılmaya mecbur kılınan çocuk) ile "sokakta yaşayan çocuk" kavramlarına bırakmış veya tanım ayrımına gidilmeye başlanmıştır (Bilgin, 2012: 81). Gelinen noktada sokakta çalıştırllan çocuklar (sokakta çalışan çocuklar) ailesinden destek alan değil ailesine destek veren, akran gruplarnyla-ailesiyle vakit geçirme, oyun gibi günlük yaşam aktivitelerinden uzaklaşan, akşamları aile evine dönen ve aileyle bağlarını devam ettirip gün içinde sokak, pazar yeri vb. mekânlarda çalışan çocukları kapsamaktadır. Sokakta yaşayan çocuklar (sokak çocukları) ise yetişkinin gözetiminden uzak veya aile evleri haricinde ve genelde kullanılmayan arazi ve konutlarda yaşayan çocukları ifade etmektedir. Başka bir deyişle sokakta yaşayan çocuklar; aile ile olan bağlılıkları devam etmeyen, evdeki mevcut sosyal sorunlardan uzaklaşan, evi terk eden çocuklardır.

Kent hayatında çocuk emeğinin anlamlandırılması "belirli bir işyerinde çalışma" ve "sokakta çalışma" durumuna göre değişme gösterirken geleneksel toplumlarda çocuğun emeği "çocuğun usta-çırak ilişkisi içerisinde bir mesleğin beceresini kazanması" çıraklık kurumu aracılığıyla normalleştirilmiştir. Ancak günümüzde çocuk emeği, zanaatkârlıktan işçiliğge doğru bir değişim izlemektedir (Yetim ve Çağlayandereli, 2007: 32).

Çocuk işgücünü kullanan, çocuğun emeğini istismar eden, eğitim gibi temel haklarını ihlal eden, fiziksel ve psikolojik yönden tehlikelere açık hale getiren çalışma alanlarından birisi de sokaklardır. Çocuğun sokakta çalıştırılması ve çalışan çocuk sayısındaki artış, önceleri büyükşehirlerde yaşanan bir sorun olarak algilanmakta iken şimdilerde hemen tüm yerleşim yerlerinde görülen bir sorun haline gelmiştir. Bu sorunun yaygınlaşmasının nedenleri arasında kültür ve sosyoekonomik yapıda meydana gelen değişmeler yatmakta (Alacahan, 2010: 134; Alptekin, 2011: 26) olup son yıllardaki yoğun mülteci akını ve terör faaliyetleri de bu sorunu tırmandıran etkenler arasında yer almakla birlikte bu çalışmanın kapsamına alınmamıştır.

$\mathrm{Bu}$ çalışmada çocukların sokakta çalıştırılma nedenleri ile karşı karşıya kaldıkları tehlike ve riskler irdelenmiş olup; sorun alanına ilişkin çocuk hakları, eğitim ve uygulama stratejileri kapsamında sosyal hizmet penceresinden değerlendirilmiştir. 


\section{Sokakta Çalıştırılan Çocukların Tanımı ve Kapsamı}

Çocuk haklart; dünya üzerindeki tüm çocukların doğuştan sahip oldukları eğitim, sağlık, barınma ve fiziksel, psikolojik veya cinsel sömürüye karşı korunma gibi haklarının tamamını içeren bir kavramdır. Çocuklar, erişkinlerden farklı özelliklere sahip olup sürekli büyür ve gelişirler. Sürekli büyüyen ve gelişen bir canlının bu durumunun farkında olmak ve ona özel bir yaklaşımda bulunmak zorunludur. Bu düşünceden yola çıkılarak dünya ulusları tarafından ilk kez 1924 yılında Cenevre Çocuk Hakları Sözleşmesi hazırlanmıştır. O günden günümüze çocuk hakları konusunda yapılan düzenlemeler; ayrım gözetmeme, çocuğun yüksek yararı, yaşama ve gelişme, isim ve yurttaşlık, anne babadan ayırmama, çocuğun görüşünün alınması, düşünce, vicdan ve din özgürlüğü hakları evrensel çocuk hakları olarak kabul edilmiştir. Uluslararası sözleşmelerin öngördügü bu yükümlülüklerin yerine getirilmesi için her devlet kendi ulusal hukukunda çocuklara ilişkin özel düzenlemeler yapmaktadır (Güngör, 2016: 206).

Birleşmiş Milletler Genel Kurulu tarafindan 20 Kasım 1989 tarihinde benimsenen ve 2 Eylül 1990 tarihinde yürürlüğe giren Çocuk Hakları Sözleşmesi, Amerika Birleşik Devletleri hariç 197 ülkenin taraf olduğu, en fazla ülkenin onayladığı insan hakları belgesidir. Türkiye'nin 14 Ekim 1990'da imzaladığı ve 27 Ocak 1995'te Resmi Gazete'de yayımlanarak yürürlüğe giren Birleşmiş Milletler Çocuk Hakları Sözleşmesi'nin (ÇHS) 1. Maddesine göre 18 yaşına kadar olan herkes çocuk kabul edilmektedir. T.C. 5395 sayılı Çocuk Koruma Kanunu'nda ise çocuk, "Daha erken yaşta ergin olsa bile, on sekiz yaşını doldurmamış kişi" olarak tanımlamaktadır.

Çocuk işçiliği (çocuk emeği); "18 yaşının altındakilere fiziksel, mental, ahlaki açıdan zarar veren ve onları eğitimden yoksun bırakarak zedeleyen, istismar eden bir çalıştırma biçimi" şeklinde belirtilmektedir (Avşar ve Öğütoğulları, 2012: 11-12; Alacahan, 2010: 136). Tunçcan'a (2000: 254) göre çocuk işçiliği; “çocuklara bedensel, ruhsal ve zihinsel kapasitelerini aşan sorumluluklar yüklemek suretiyle gerçekte istismara dönüşmüş bir mekanizmayı" ifade etmektedir. Bir başka tanımla çocuk işçiliği; çocukların sağlıklı bireyler olarak "toplumsallaşma" sürecine katılabilmelerini engelleyen, toplumsal hayat sürecinde sosyal dışlanmaya maruz bırakan çalışma biçimi olarak ifade edilmektedir (Şen ve Kahraman, 2012: 168).

Çalıştırılan çocuk olgusu, "çocuğun hayatın ileri evrelerine ait etkinlik ve sorumluluk alanına gereğinden çok evvel giriş yapması, sıralı ve düzenli yaşama sürecinden kopuşu" olarak tanımlanmaktadır (Fidan, 2004: 46). Çalıştırılan çocuk; "18 yaşının altında olup sosyo-ekonomik kazanç sağlamak amacıyla esnaf ve sanatkârlar yanında ya da sanayi iş kolunda çalışan çocuklarla, tarım kesiminde ailesi ile birlikte çalışan çocuklar" olarak ifade edilmektedir (Avşar ve Ögütoğulları, 2012: 11-12; Alacahan, 2010: 136). Karabulut'un (1996: 22) ifadesiyle ise; "Aile bütçesine katkıda bulunmak ve bir meslek ögrrenmek amacıyla genellikle küçük sanayide, enformel sektörde, tarımsal alanda, esnaf ve sanatkârlar yarımda, marjinal çalışma alanlarında, işyerlerinde, evde, sokakta çalışan küçük yaştaki kimselerdir."

İngilizcede çalışan çocuğun istismarı ve ihmali kavramını karşılamak için "çocuk işçiliği" (child labour) terimi kullanılırken, çocuğun istismar ve ihmale uğramadan çalışması "çocuk çalışması" (child work) anlamına gelmektedir. Çocukların yoğun olarak çalışmakta olduğu alanları dışta bırakan terminoloji, tanım 
ve yaklaşımlardan kaçınılması ve soruna yönelik çocukların çalıştığı tüm sahayı içeren bir yaklaşım geliştirilmesi gerekmektedir. Günümüzde dünya nüfusunun çoğunluğunu barındıran, sosyo-ekonomik açıdan geri kalmış ve gelişmekte olan ülkelerde çalıştırılan çocukları "işçi”" olarak isimlendirmenin pek mümkün olmadığ 1 görülmektedir. Örneğin; çocukların bir kısmının ücretsiz olarak ya da küçük işyerlerinde çırak olarak çalıştırıldığı, kız çocukların önemli bir bölümünün ev işlerinde, erkek çocukların ise giderek artan oranda sokaklarda çalıştırıldıkları gözlenmektedir. "İşçi”" olarak adlandırılmasalar da çocukların birçoğu, sosyal hayata özgü ihtiyaçları karşılanmadan istismara maruz kalabildikleri ortamlarda çalıştırılmaktadırlar. Bu bağlamda, "çocuk işçiliği”"nin sadece ücret karşılığında çalışmayla sınırlı olmadığı, olguyu "çalıştırılan çocuğun istismarı ve ihmali" olarak ifade etmenin daha kapsayıcı olacağı kanaati ortaya çıkmaktadır (Zeytinoğlu, 2001: 50-51).

"Çalıştırılan çocuk" kavramı sokakta çalıştırılan çocukları da kapsamakla birlikte tarım, sanayi ve hizmet sektöründe çalıştırılan çocukları içermektedir. Bu çocuklar kırsal alanlarda tarım işlerinde, kentsel alanlarda ise sokakta, küçük atölyelerde ve ev işlerinde çalıştırılmaktadır. Gecekonduda yaşayan aileler ise çocuklarıyla birlikte mevsimlik tarım işlerine gitmektedir. Kırsal alandan kentsel alana geçişte yaşanan üretim yapısındaki değişiklik sebebiyle formel sektörde istihdam edilemeyen yetişkinler, çocukların kazandığı paraya ihtiyaç duymuş ve böylece enformel sektörde çocukların işgücü kullanılmıştır (Yıldız, 2007b: 138). Çocuklar, kemer, deri, gömlek, çanta vb. ürünler başta olmak üzere imalat işleri, taşımacılık, işportacılık ve pazarcılık gibi sokakta yapılan işler; lokanta, büfe, kahvehane, bakkal vb. vasıfsız hizmet sektörü işleri gibi başlıca enformel işlerde çalıştırılmaktadır (Şen ve Kahraman, 2012: 181).

Çocuk ve Gençlik Merkezleri Yönetmeliği'nin (2001-Mülga), 4. Maddesinde sokakta çalıştırılan çocuk, "Ailesiyle ilişkisi az veya çok devam etmekle birlikte günün önemli bir bölümünde, aile denetimi ve desteği olmaksızın, yaşadiğgl mekândan uzakta kendi isteği veya ailesinin isteği ile çalıştırllan, ĕgitim olanaklarından kısmen veya tamamen yoksun bırakılmış 7-18 yaş grubu çocuk" olarak tanımlanmıştır. Çocuk Destek Merkezleri Yönetmeliği'nde (2015) ise bu yönetmelik ve sokakta çalıştırılan çocuğun tanımı kaldırılmış olup, 3. Maddesinde "Sokakta Yaşayan Çocuk"un tanımına yer verilmiştir (cocukhizmetleri.aile.gov.tr).

Türkiye'de çocuk işgücünün kullanımına tarihsel açıdan bakıldığında ilk örneklerinin Osmanlı döneminde Ahi kurumlarında görüldüğü söylenebilir. Çalışanlar çırak-kalfa-usta hiyerarşisi içinde, baba-evlat enformel ilişkisi ile idare heyetinin denetim ve gözetimi altında çalıştırılmıştır. Her çırak okuma-yazma öğrenirken her usta çıraktan ahlaki açıdan sorumlu olmuştur. Tarımda aile temelli çalışan çocuklar, Osmanlı sanayileşme dönemine geçiş sonucunda sanayi ve hizmet sektöründe de çalışmaya başlamıştır. Cumhuriyet döneminde ise çocuk işgücü mesleki teknik eğitimin bir parçası olarak görülmüştür (Avşar ve Öğütoğulları, 2012: 25).

Geleneksel kültürde devam eden "çıraklık" kurumu, kentlerde yaygınlaşan küçük ölçekli işletmelerde geleneksel toplumlarda kabul edilen "zanaat" anlayışından farklı olsa da çocuk emeğinin "çıraklık" adı altıda istihdam edildiği görülmektedir (Erder ve Lordoğlu, 1993: 12). Köy ve kent açısından 
değerlendirildiğinde "çocuk" ve "işgücü" geleneksel ve modern bağlamda farkl11ıklar göstermektedir. Geleneksel anlamda çocuk işgücü, aile içinde "kabul gören bir kültürel olgu" olup ailenin varlığını devam ettirmesinde ortak eylemler bütününün bir parçasıyken ve yetişkinlik dönemi için gerekli bilgi ve beceriyi sağlayan bir hazırlık dönemi olarak görülürken; kentleşme ile birlikte çocuk işgücünün anlamı "eğitim aracılı̆̆ıyla kazanılmış mesleki formasyon" ile birlikte düşünülmeye başlanmıştır (Yetim ve Çağlayandereli, 2007: 34,54).

Hukuk sistemimiz çocuğun çalışması durumu ile ilgili bazı düzenlemeler yapmıştır. Buna göre 15 yaşını doldurmamış çocukların çalıştırılmaları yasaktır. Ancak, 14 yaşını doldurmuş çocuklar çıraklık yapabilir veya hafif işlerde çalıştırılabilirler. Çırak; bir meslek dalında mesleğin gerektirdiği bilgi, beceri ve iş alışkanlıklarını geliştirmek için çalışan kişidir. Çıraklık yaptığı kişi ya da kurum ile bir sözleşme yapar ve bu sözleşmede belirlenen kurallara tabi olur. Çırak işçi değildir. Dolayısıyla çıraklar hakkında İş Kanunu uygulanmaz. Çıraklar 3308 sayı1ı Mesleki Eğitim Kanunu'na tabidirler. Çalışan çocuklar ise "işçi” statüsüne tabi olmakla beraber yetişkinlerden ayrı olarak belli birtakım haklara sahiptirler (Güngör, 2016: 209).

Bequele ve Myers'a (1998: 1) göre Batı'da çocuklar, tarım işlerinde, sanayi işlerinde (cam eşya üretimi, inşaat ve halı dokumacılığı gibi), ev ve sokak işlerinde (çöplerdeki atıkları toplama, satıcılık, fahişelik gibi) çalıştırılmaktadır. Tarım alanında makine ve kimyasal madde kullanımı nedeniyle çeşitli riskler bulunmakta, sokakta çalıştırılan çocuklar sokak çetelerinin şiddet ve tehdidine maruz kalabilmekte, ev işlerinde çalıştırılan çocuklar ise oyun ve eğitim haklarından mahrum kalabilmektedir.

Rodgers ve Standing (1981: 2-8) ise, çocukların çalıştırıldıkları alanları sınıflandırmıştır:

- Ev işleri: Temizlik, yemek pişirme, çocuk bakımı vb. ev işlerini içermektedir.

- Ev işi olmayan ücretsiz işler: Aile bütçesine katkı sağlamak amacıyla yapılan ücretsiz işleri kapsamaktadır.

- Bağımlı ya da sözleşmeli işçilik: Bazı aileler, çocuklarını borç karşılığında kiralamaktadır.

- Ücretli işçilik: Mal ya da para karşılığında çocuğun çalıştırılmasıdır.

- Marjinal ekonomik faaliyetler: İssportacılık, çöp toplayıcıllığı, dilencilik, fahişelik, hırsızlık ve diğer illegal faaliyetleri içermektedir.

Sokakta çalıştırılan çocuklar, genellikle seyyar satıcılık yapma, hamallık, ayakkabı boyama, simit, sakız, şeker, balon, çiçek, su ve buz gibi eşyaları satma, otomobillerin camlarını silme, çöp toplama, su taşıma, mezarlıklarda temizlik işleri gibi geçici işlerde çalışmakta ve sıklıkla iş değiştirmektedir (Karabulut, 1996: 26; Kızmaz ve Bilgin, 2010: 299). Basit, işlevsel ve gündelik hayatın içinde olan hareketli işlerde çalışmaktadırlar. Bu işlerin kolay ve erişilebilir olması çocukları çalışmaya heveslendirmekte ve çekmektedir.

Özyanık (1998: 94-96; akt. Günşen İçli, 2009: 20), sokakta çalıştırılan çocukların yoğun olarak yaptıkları işleri 3 türde gruplandırmıştır: 
Tablo 1: Sokakta Çalıştırılan Çocukların Yoğun Olarak Yaptıkları İşler

\begin{tabular}{|c|c|c|}
\hline Sermaye Yoğun İşler & Emek Yoğun İşler & $\begin{array}{c}\text { Sokağı Mesken } \\
\text { Edinen Çocuklar, } \\
\text { Dilenciler ve Sokak } \\
\text { Çeteleri Tarafından } \\
\text { Yapılan İşler } \\
\end{array}$ \\
\hline Sermaye isteyen & $\begin{array}{l}\text { Sermayeye dayanmayan ya } \\
\text { da çok az sermaye isteyen }\end{array}$ & Yoğun emek isteyen \\
\hline $\begin{array}{l}\text { Simit, balon, su, çiçek, } \\
\text { tatlı, ay çekirdeği, mısır, } \\
\text { kestane, naylon poşet, } \\
\text { peçete, çiklet, kuşyemi } \\
\text { gibi malları satmaktadır. }\end{array}$ & $\begin{array}{l}\text { Hamallık, küfecilik, el } \\
\text { arabasıyla taşımacılık, } \\
\text { ayakkabı boyacılığı, (cam, } \\
\text { teneke, plastik, kâğıt) vb. katı } \\
\text { atık toplayıcılığı gibi işlerdir. }\end{array}$ & $\begin{array}{l}\text { Otoparkçılık, mezarlık } \\
\text { işleri, tartıcılık, cam } \\
\text { siliciliği, kavşak } \\
\text { satıcılığı gibi işlerdir. }\end{array}$ \\
\hline
\end{tabular}

(Bilgiler, Günşen İçli’nin (2009) çalışmasından alınmış olup tarafımızca tablo haline getirilmiş̧ir.)

Alacahan'ın (2010: 138-139), sokakta çalıştırılan çocukların ve ailelerinin sosyo-ekonomik yapısını ve çocuğun çalıştırılmasına ilişkin ebeveynlerinin tutumlarının belirlenmesini amaçlayan araştırmasında; çocukların çalışma süresinin mevsim şartlarına göre değişim gösterip büyük bir çoğunluğunun 1-12 ay süreyle (\%80 ile) sokakta çalıştı̆̆ı tespit edilmiştir. Sokakta çalıştırılan çocukların yine büyük çoğunluğunun (2010 yılı şartlarında \%75 ile) aylık kazancının ortalama 75100 TL olduğu görülmektedir.

Alparslan ve Karaoğlan'ın (2012: 169-171), "Sokakta Çalı̧̧an Çocukların Yaşam Koşulları" adlı araştırmasında sokakta çalışan çocukların anne (\%100 ile) ve babalarının (\%91,4 ile) eğitim düzeylerinin çok düşük olduğu, lise ve yüksekokul mezunu anne olmadığı, ortaokul-lise mezunu baba oranının \%16 olduğu, sokakta çalışan çocukların çoğunluğunun 3 çocuk veya üzeri sayıda çocuğa sahip çok çocuklu ailelerden geldiği, babaların çoğunluğunun (\%64,5 ile) işinin olduğu ve inşaat işçiliği gibi düşük kazançlı işlerde çalışırken, geri kalanı da işsiz ve annelerin tamamının gelir getiren hiçbir işte çalışmadığı tespit edilmiştir. Bununla birlikte sokakta çalıştırılan çocukların babalarının vasıfsız işte çalışması yahut işsiz olmasının alkol $(\% 97,8$ 'i) ve sigara $(\% 93,5)$ tüketimini azaltmadığı görülmektedir. Alacahan'ın (2010: 139-140) araştırmasında, (\%55 ile) babaların mesleği ve çalıştığı işler "mesleksizlik" olarak nitelendirilmektedir. İşsiz olan babaların daha çok vasıfsız işlerde ve ara işlerde günübirlik çalıştıkları işler vasıtasıyla gelir elde ettikleri görülmüştür. Annelerin ise çoğunun "ev hanımı" oldukları ve gelir getiren herhangi bir işte çalışmadıkları tespit edilmiştir.

Çalıştırılan çocuklar, çalışmayan yaşıtlarıyla kıyaslandığında bedensel ve psikolojik gelişimlerinin akran gruplarına nazaran geri kalmış olduğu, yaşıtlarına oranla daha kısa boylu ve zayıf oldukları ve kendine güvensizlik/ değersiz olma hissi yaşadıkları belirtilmektedir. Bununla birlikte çalıştırılan çocuklara yüklenen sorumluklar çocuk olmaktan kaynaklanan ihtiyaçlarıyla çelişmektedir. Ebeveynlerin onları algılama biçimi ve beklentileriyle kimi zaman çocuk kimi zaman ise çalışan nitelikleriyle ön planda olmakta, yani iki kimliği de muhafaza etmeleri gerekmektedir. Bu durumun bir benzeri işverenler için de söz konusudur. Çalışma süresi, koşulları ve verimlilik vb. konularda çocuğun yetişkinlerle aynı performansı 
göstermesini beklemekte, ödenecek ücret miktarı ve iş güvenliği gibi konularda çocuk olma niteliği ön planda olmaktadır (Tunçcan, 2000: 253-254).

Anayasanın 50. maddesine göre "Kimse yaşına, cinsiyetine ve gücüne uygun olmayan ișlerde çalıștırılamaz. Küçükler ve kadınlar ile bedenî ve ruhî yetersizliği olanlar çalışma şartları bakımından özel olarak korunurlar." biçiminde ifade edilerek çocukları çalışma hayatında koruyacak önlemlerin alınmasına vurgu yapmaktadır. İlköğretim ve Eğitim Kanunu'nun 59. Maddesi'nde ise "İlköğrenim çağında olup da mecburi ilköğretim kurumlarına devam etmeyenler, hiçbir resmi ve özel iş yerinde veya her ne surette olursa olsun çalışmayı gerektiren başka yerlerde ücretli veya ücretsiz çalıştırılamazlar.” denmektedir.

20. yüzyıla değin yaşanan gelişmeler ve özellikle Uluslararası Çalışma Örgütü'nün (ILO) kurulmasıyla, çocuk işçiliği sorunu uluslararası boyutta ele alınmıştır (ILO; Şen ve Kahraman, 2012: 169-170; Avşar ve Öğütoğulları, 2012: 13-14):

- 1919 yılında Uluslararası Çalışma Konferansı toplantısında, çocuk işçiliğine ilişkin ilk sözleşme "5 Numaralı En Az Çalışma Yaşı Sözleşmesi” kabul edilmiştir. Bu sözleşme kapsamında 14 yaşından küçük çocukların endüstriyel işletmelerde çalışmaları yasaklanmıştır.

- 5 Numaralı Sözleşme'yi izleyen 50 yıl boyunca, 9 sözleşme daha kabul edilmiş; endüstri, tarım, denizcilik, endüstri-dışı, balıkçılık yer altı işleri gibi farklı sektörlerde en az çalışma yaşı özel sözleşmelerle düzenlenmiştir.

- ILO’nun 1973 yılında kabul ettiği 138 Sayılı Sözleşme ile birlikte 15 yaşını doldurmamış kişiler "çocuk işçi", 15-24 yaş arasını "genç işçi" olarak kabul edilmiştir.

- Çocuk işçiliği ile mücadele eden ulusal programlara uluslararası destek sağlamak amaciyla 1992 'de ILO, Çocuk İşçiliğinin Ortadan Kaldırılması Uluslararası Programı'nı (IPEC) başlatmıştır.

- 1995’te Kopenhag Sosyal Gelişme İçin Dünya Zirvesi’nde çocuk işçiliğinin tüm ülkelerde yasaklanması için bir bildirge ve eylem planı kabul edilmiştir.

- 1998'de Uluslararası Çalışma Örgütü, “Çalışma Yaşamında Temel İlkeler ve Haklar Bildirgesi”ni kabul etmiştir.

- ILO'nun 1999 yılında kabul ettiği bir diğer sözleșme de 182 No’lu "Kötü Şartlardaki Çocuk İşçiliğinin Yasaklanması ve Ortadan Kaldırılmasına İlişkin Acil Önlemler Sözleşmesi”dir. Sözleşmenin 1. Maddesi'nde, "Sözleşmeyi onaylayan her üye ülke acil bir sorun olarak en kötü biçimlerdeki çocuk iş̧̧iliğinin yasaklanmasını ve ortadan kaldırllmasını temin edecek ivedi ve etkin önlemler almasını" şart koşmakla birlikte 2. Maddesi'nde "Çocuk teriminin 18 yaşın altıdaki herkese uygulanacağını" belirtmektedir. 3. Maddesi'nde ise "en kötü biçimlerdeki çocuk işçiliği” ifadesinin tanımı yapılmıştır. Bu tanıma göre, çocukların, "borç karşılığı veya bağımlı olarak çalıştırılması" ve "askeri çatışmalarda çocukların zorla ya da zorunlu tutularak kullanılmasını da içerecek şekilde zorla ya da mecburî çalıştırılmaları", "çocuğun özellikle ilgili uluslararası anlaşmalarda belirtilen 
uyuşturucu maddelerin üretimi ve ticareti gibi yasal olmayan faaliyetlerde kullanılmasını" içeren şartlar itibariyle çocukların sağlık, güvenlik veya ahlaki gelişimleri açısından zararlı olan işleri kapsamaktadır.

\section{2. Çocukların Sokakta Çalıştırılma Nedenleri}

Ailelerin mevcut gelir düzeyindeki düşüklük çocuklarının kazandığı paraya ihtiyaç duymasına neden olmaktadır. Sanayileşme sürecini tamamlamamış, nüfus artış hızı yüksek, genç nüfusun fazla olduğu ülkelerde ailelerin eğitime yaklaşımı sıklıkla yoksulluğun baskısı altında kalmaktadır. Bunun yanında işverenlerin çocuk işgücünü tercih etmesi de diğer bir nedeni oluşturmaktadır. Çoğunlukla kayıt diş1 çalıştırıldıkları ve haklarını arama konusunda bilinç düzeylerinin düşük olması nedeniyle işverenler tarafindan çocuklar tercih edilmektedir. Bir başka neden ise sorun alanına ilişkin ilgili mevzuat eksiklikleri veya mevzuatın etkin uygulanmamasıdır. İşyerlerinin denetiminin etkin yapılamaması, cezai yaptırımların yetersizliği, denetim yapan kurum ve kişilerin çocuk işgücünün kullanılmasını göz ardı etmeleri gibi nedenler bu alandaki denetimi ve yaptırımı yetersiz kılmaktadır (Avşar ve Öğütoğulları, 2012: 12).

Genç (2016), çocukların çalıştırılma nedenlerini şu şekilde sıralamaktadır: ekonomik krizler, artan yoksulluk, adaletsiz gelir dağılımı, kayıt dışı ekonominin giderek büyümesi, düşük ücret politikaları, sivil toplum örgütlerinin etkin olmaması, işsizliğin artması, plansız ve kontrol dışı nüfus artışı, hızla ve plansız kentleşme, yetersiz ve niteliği düşen eğitim yapısı, geleneksel ve kültürel koşulların baskısı, ailelerin çocukları gelir aracı olarak görmesi ve bir an önce meslek edinme isteği. Ayrıca, okullardaki başarısızlık oranlarının yüksekliği, boş zaman değerlendirme alışkanlıkları ya da olanaklarının olmaması, eğitimde firsat eşitliğinin olmaması ya da düşük olması, ailelerin eğitim düzeylerinin düşük olması, eğitim maliyetlerinin yüksek olması, ulusal düzeyde sivil toplum örgütlerinin etkinliğinin az olması, hükümetlerin konuya gösterdiği önemin yetersiz kalması ve toplumun duyarsızlı̆g 1 da çocukların çalıştırılmasına/emeğinin sömürülmesine neden olmaktadır.

Tunçcan (2000: 243-250), çocuk işgücünün kullanılmasına ilişkin sebepleri "çocukları emek arz etmeye zorlayan faktörler" ve "işverenlerin emek talepleri" olmak üzere iki açıdan sınıflandırmıştır. Çocukları emek arz etmeye zorlayan faktörler; yoksulluk, işsizlik, hızlı ve çarpık kentleşme, nüfus, eğitim düzeyi ve gelenekler olarak ifade etmiştir. Gelir yetersizliği ailelerin tüm kaynaklarını arz etmeye zorlamaktadır. Çocuklar da vasıflı işgücüne sahip olmadıkları için çok düşük ücretler karşıllı̆ı çalıştırılmaktadır. Hızlı nüfus artışı ise, düzensiz kentleşme, kentsel işsizlik gibi sorunlara neden olmakta, aile gelirindeki hızlı düşüşler çocukları da etkilemekte, bu durum tüm aile üyelerinin çalışmaya mecbur bırakmaktadır. Böylece hızlı düşen gelir düzeyi, okul çağındaki çocukların eğitim hayatından uzaklaşmasına neden olmaktadır. Aileler ve çocukları için eğitimin maliyeti iki boyutludur. Eğitim harcamaları için ailenin bütçesinden kaynak ayrılması gereği olan dolaysız maliyet, diğeri ise eğitime yönelen çocuğun iş piyasalarına emek arz etmemesinden dolayı ailenin mahrum kalacağı potansiyel kazançtan oluşan "fırsat maliyeti", dolaylı maliyettir. İşverenler açısından çocuk emeği, ucuz işgücü maliyeti anlamına 
gelmektedir. İşverenlerin işgücü maliyetlerini düşürebilmek için emek taleplerini çocuklara yöneltebilmesinde kayıt dışı ekonomi de etkili olmaktadır.

Güneş ve Kalaycı (2004: 7), çocuğu sokağa iten nedenleri şu şekilde s1ralamaktadır:

1) Göç ve uyum sorunları,

2) Ekonomik sorunlar (yoksulluk, yoksunluk, işsizlik),

3) Aile içi sorunlar; aile içi cinsel taciz, tecavüz ve şiddet, çocuğun ihmal/istismar edilmesi, ailenin parçalanması, ailenin yapıcı olmayan tutum ve davranışları, ailenin ve çocuğun eğitimsizliği,

4) Çarpık kentleşme,

5) Sokağın cezbedici yönü ve görece özgürlüğü,

6) Denetimsiz oyun salonların cezbedici yönü,

7) Akran grupları,

8) Soruna yönelik çalışan gönüllü kuruluşlarının bilgi yetersizliği, profesyonel yaklaşımlarının yoksunluğu,

9) Medyanın olumsuz yayınları,

10) Çocukların para kazanmasını teşvik edici kültürel değerler,

11) Yardımseverlik/ hayırseverlik anlayışıyla (acıma duygusuyla) yetişkinlerin para vb. eşyalarla yardım yapması.

ILO ise, çocuk işçiliğine neden olan faktörleri; "gelenekler, eğitime ulaşabilmede yaşanan sorunlar ve yoksulluğa açıklık" şeklinde belirtmektedir. Bununla birlikte çocukların, sokağa yönelmelerinin ve sokakta çalışmalarının nedenleri arasında "sağlıksız yerleşme, yoksulluk (ekonomik sorun kaynaklı olarak ailenin çocuğa yönelik duygusal istismarı), bölüşüm adaletsizliği, bölgesel eşitsizlikler ve eğitim imkânlarından yararlanamama" gibi etkenler söz konusu olmaktadır (Yetim ve Çağlayandereli, 2007: 35-36).

Çocuk işçiliğinin temel nedenleri; yoksulluk, göç, geleneksel bakış açısı, eğitim imkânlarının yetersizliği ve etkin uygulanamamasıdır (Tor, 2010: 32). Bununla yanında, sokakta çalıştırılan çocuk sayısının artmasındaki en önemli unsur; "kitlesel göç"lerin neden olduğu "kentsel yoksulluk"tur. Doğu ve Güneydoğu Anadolu'da devam eden terörle mücadele faaliyetleriyle birlikte 90'l1 yılların başında ve sonunda yoğunlaşan kitlesel göçler ve bu göçlerin sebebiyet verdiği sosyal sorunlar -sosyal dişlanma, sosyal sermayedeki dönüşümler, yoksulluk, işsizlik, suç ve şiddet gibi- arasında temel olarak yaşanan ekonomik sorunlar; ebeveynlerin kentlerde işsiz kalarak çocukların sokağa yönelmelerine ve sokakta çalışmalarına neden olmuştur (Kızmaz ve Bilgin, 2010: 271-272, 274). Bu süreç, Nisan 2011'den bu yana ülkemize sığınan Suriyeli mülteciler örneğinde daha belirgin şekilde devam etmektedir.

Ailelerde görülen yoksulluk, eğitimsizlik veya erken yaşta göç, iş piyasasına dâhil olma gibi pek çok özelliğin sonraki kuşaklara aktarıldığı bir süreklilik söz konusudur. Yoksulluğun neden olduğu, çocuk ve genç işçilerin anne babaları ile kendi eğitim durumları arasında paralellik vardır (Şen ve Kahraman, 2012: 184). Bununla birlikte, anne ve babaların eğitim düzeyindeki düşüklük, çocukları için eğitimin uzun vadede yararlı çıtılarını öngörememelerine ve özellikle kız çocuklarının eğitim almalarında çaba sarf etmemelerine neden olabilmektedir (Zeytinoğlu, 2001: 87). 
Çalıştırılan çocuklar, çalıştığı çevre içindeki kişileri model alması ve eğitim sürecinde yaşadığı maddi ve manevi sorunlar nedeniyle okula karşı isteksizlik göstermektedir. Çocukların okullara karşı isteksizliği, çalıştığı için önemsenmesi ve gelir sahibi olmanın verdiği güç temel faaliyet alanını okuldan/eğitimden çıkartıp iş hayatına doğru değiştirmiştir (Fidan, 2004: 34). Köksal ve Lordoğlu (1993) araştırmasında; çocukların çeşitli nedenlerden kaynaklanan eğitim kurumlarına karşı "güvensizlik" ve "isteksizlikten" dolayı eğitimden uzaklaştıklarını belirtmektedir. Genellikle verilen eğitimin arz oluşturan iş piyasasına uymaması, eğitime devam edenlere nitelik kazandırmaması, eğitimini tamamlamış gençler arasında oluşan işsizlik-hayat standartlarının düşüklüğü algısıyla birlikte eğitim kurumlarının "sevimsiz" algılanması gerekçesi gibi etkenler gösterilmektedir.

Şen ve Kahraman (2012: 179-180), Türkiye'deki içgöç, yoksulluk ve istihdam ilişkisini tespit etmeyi amaçlayan araştırmasında çocuk işçilerin çoğunun babası ya da ağabeyinin yanında, bir kısmının da amca, dayı, amcaoğlu gibi birinci dereceden akrabalarının tecrübe ve güvencesi altında göç ettiklerini ve çalıştıklarını ortaya koymuştur. Çalışan çocukların babalarının ve annelerinin düşük bir eğitim düzeyine sahip olduğu ifade edilmiştir. Çocukların ise erken yaşta çalışma zorunluluğu, eğitime devamda isteksizliğine sebebiyet vermiştir. $\mathrm{Bu}$ durum, çocuklar tarafindan şu şekilde ifade edilmiştir:

"Kendim gelmek istedim. Abim de gel dedi. Girdim çalışmaya. Okul açılınca eve giderim. Şimdi 8. Sinıftayım, ilerisini okumayı düşünmüyorum. Okul bitince buraya geleceğim çallşmaya. Bağımız var ama kendimize yetecek kadar, satacak kadar yok.." "Sikıcı olduğu için okumadım. Bana bağlı okumak. İnsan kendi işinin sahibi olunca daha iyi, şimdi değilim ama ileride olacak, kendime bir kemer atölyesi kuracağım... Köyden sipariş ettiler beni. İş̧i lazımdı geldim. İstanbul iyidir. Bizim köydeki gençler hep Istanbul'da, başka yerlere gitmiyorlar."

Kızmaz ve Bilgin'in Diyarbakır kent merkezinde sokakta çalışan ve kısmen de sokakta yaşayan çocukların suçluluk durumlarını inceleyen araştırmasına göre çocuklar sokakta çalıştıkları için memnuniyet duymaktadır. Çocukların sokakta çalışmasının önemli bir nedenini oluşturan yoksulluk, çocukların ailelerine sunduğunu düşündüğü ekonomik destek beraberinde bu memnuniyeti getirmektedir. \%28,6 ile aileye sağlanan kazanç ve \%23,8 ile kendi ihtiyaçlarını karşılaması memnuniyetin nedenlerini oluşturmaktadır. Bununla birlikte çocuklar, çalıştıkları zamanlarda \%19 ile kendi geleceklerini hazırladıklarını ve \%19 ile akran gruplarıla birlikte hoşlandıkları şeyleri yapma imkânına sahip olduklarını ifade etmiştir (2010: 300-301). Sonuç olarak, çocukların sokağa yönelmesinde ve sokakta çalışmasında duyduğu memnuniyet; aileye sağladıkları ekonomik destek ve sokağın cezbediciözgür yanı ile ilişkilidir. Lakin çocukların çok erken yaşlarda iş hayatına dâhil olmalarının sebebi çocukların tercihlerinin bir sonucu değil aksine bir mecburiyetin sonucudur (Y1ldız, 2007b: 141).

Nüfus artışı, çalıştırılan çocuklar sorunu olgusunun önemli bir kaynağıdır. Çocuk yetiştirme bilincinin yoksun olduğu, yetersiz gelire sahip ailelerde ve özellikle eğitim seviyesinin düşük olduğu ailelerde çocuk sayısı fazla olmaktadır. Bu ailelerde aile planlamasının bilinmeyişi, yetersiz olan gelirin daha fazla kişi tarafindan paylaşılması ve zorunlu ihtiyaçların karşılanmasında mevcut gelirin yetmeyişi, aile fertlerinin her birinin çalışmasını zorunlu kılmıştır (Fidan, 2004: 33). 
Hızlı nüfus artışı, eğitim, sağlık vb. temel refah hizmetlerinden yararlanabilme imkânlarını hem bireysel hem yerel düzeyde azaltarak, çok çocuk sahibi olmanın ise aile bütçesini zorlaması sebebiyle çocukların çalıştırılmasına kap1 aralanmaktadır (Zeytinoğlu, 2001: 85; Yıldız, 2007b: 139).

Gelişmekte olan ülkelerin bir kısmında yüksek işsizlik oranıyla birlikte istihdama açık işler de bulunmaktadır. Emek piyasasındaki yetersizlik sonucu oluşan bu durum aynı zamanda enformel çıraklık düşüncesinin yaygınlığının bir sonucu olarak çocukların küçük yaşlarda vasıfsız işlerde çalışmalarına neden olmaktadır. Çok çocuklu geniş bir aileye sahip olan aile reisleri, kırdan kente göç ettiklerinde kentsel emek piyasalarında aranan vasıflara sahip olmamaları nedeniyle, kendilerine gelir sağlayacak yeterli işi imkânı bulamamaktadır. Bu sebeple, ailedeki diğer üyeler aile bütçesine katkı sağlamak için çaba göstermekte ve aile reisleri vasıfsız bir işe sahip olana kadar "işçileşme" sürecinden geçmektedir. "Şevki kırılmış işçi" etkisinin de çalışmamada bir etken olduğunu ve aynı zamanda kente göç etmiş bireylerin uzun zaman bir iş bulamaması karşısında bir vazgeçişi olarak nitelendirilebilir. Bu süreç neticesinde çalıştırılan çocukların fazla oluşu ve toplam gelirlerinin göreli olarak yüksek olması ile çalışmayan aile reisleri, yalnızca bir organizatör konumuna gelmekte ve çalışmaya ihtiyaç duymamaktadır (Baştaymaz, 1990: 29-30).

Maliyeti düşük ve kolay yönetilebilen/yönlendirilebilen bir işgücü niteliği taşıması ve bazı işlerde, yetişkinlerin işi yapmak istememesi, bazen de çocuk işgücünün işi yapmaya uygun görülmesi nedeniyle çocuklar ebeveynlerinden daha kolay iş bulabilmektedir. $\mathrm{Bu}$ durum, çocukların belirli işyerlerinde "yetişkin işgücüne alternatif” olarak görülmesine neden olmuştur (Fidan, 2004: 32-33).

İşverenlerin ise çocukları "ücretli emek" olarak çalıştırmalarının nedenleri arasında ekonomik boyut vurgulanmaktadır. İşverenler, çocuk emeğinin karşıllı̆ının düşük olması, çocukların yetişkinlere göre daha az hünerli/üretken olmaları ve haklarını arayamaması gibi nedenlerle çocuk işgücünü tercih etmektedir. Bununla birlikte çocuk ve kadın emeği, yetişkin erkek emeğinin tamamlayıcısıdır. Yani, kadın ve çocuklar, "eve ekmek getiren aile reisinin" ücretinin düşük olması durumunda hane gelirine katkıda bulunmak amacıyla iş piyasasına katılmaktadır (Erder ve Lordoğlu, 1993: 12-13; Karabulut, 1996: 10).

\section{Sokakta Çocukları Bekleyen Riskler ve Tehlikeler}

Sokakta çalışan çocukların ailelerinin yaşadığı yoksulluk, zorunlu göç, terör vb. sorunlar nedeniyle yaşanan travmalar çocukları dezavantajlı konuma sürüklemektedir. Bununla birlikte, aile bireylerinin geçiminden çocuğun sorumlu olduğuna yönelik inancı, eğitimin hayat üzerindeki öneminin kavranamaması, kız çocuklarının erken yaşta evlendirilmesi gibi bazı olumsuz geleneksel değerler çocukların ihtiyaçlarının karşılanmasında duyarsızlığa yol açmış ve çocukları çeşitli risklere açık hale getirmiştir. Sokakta çalışan çocukların maruz kaldıkları şiddet, ihmal ve istismar, "başkalarına şiddet uygulama, evden-okuldan kaçma, okulda başarısızlık, madde kullanma ve bağımlısı olma, sokaktaki suç gruplarına katılma, psikolojik ve sosyal problemler yaşama" gibi sosyal sorunların yaşanmasının önünü açmıştır (Bilgin, 2012: 83). 
Çalıştırılan çocuklar, uzun çalışma süreleri, kötü ve sağlık şartlarda çalıştırılması, düşük ücret, sosyal güvenlik haklarından yararlanmama ve yetersiz beslenme gibi çeşitli risk ve tehlikelerle karşılaşabilmektedir. Ayrıca çocuklar fiziksel ve cinsel yönden istismara açık ortamlarda çalışmaktadır. Çocuklar emniyet güçleriyle karşı karşıya gelebilmekte, çeşitli suçlara karışabilmektedir. Bu çocuklar sıklıkla okulu terk etmekte, hanede yaşanan sorunlar arttı̆̆ında evden kaçmakta ve zamanının büyük bir kısmını sokakta geçirmektedirler (Karabulut, 1996: 24-26).

Yalnızca erişkin işçiler dikkate alındığında, fiziksel sağlığa ve güvenliğe yönelik tehditler "risk" kelimesiyle ifade edilir. Bu doğrultuda, işyerindeki tehlikeleri asgari düzeye indirmek için iş kazalarını ve meslek hastalıklarını önlemek amaçlanır. Bu önlemler, inşaatta çalışan erişkin işçilerin koruyucu elbise giymesi, fabrikada çalışan erişkin işçilerin elektrikli cihazları kullanmada güvenlik önlemlerine uymaları konusunda yapılan eğitimler gibi olabilmektedir. Çocuklar ise erişkinlerin çalıştıkları alanlarda karşılaştıkları "risklerle" daha fazla karşı karşıya gelmektedir. Çocuğun yaptığı iş ve kullandığ 1 aletler için yaşının küçük olması, çalışma saatlerinin uzun sürmesi, yüklenen sorumluluğun fazla olması, işin sıkıcı, tekdüze ve çocuğun gelişimine katkısı olmayan bir iş olması, kimyasal madde, aşırı sıcaklık ve gürültü gibi tehlikeli bir ortamda çalışması, özgürlüklerinin kısıtlandığ bir ortamda çalışması, hangi işi yapmak istediklerinin sorulmamış olmasının işi bırakamaya ya da özsaygılarını yitirmeye yol açması, çocuklara bedensel, ruhsal, duygusal, sosyal ve ahlaki yönden gelişimlerine uzun erimde zarar vermektedir (Ennew, 1998: 29; Bequele ve Myers, 1998: 3-4).

Tarımsal üretimin düşüklüğü ve küçük ölçekte tarım işletmelerinin verimsizliği gibi nedenler göçe neden olmaktadır. Ailedeki yetişkin erkeklerin kente göç etmesi durumunda ise geride kalan çocukların işgücünün kullanımı artmaktadır. Aileleriyle göç eden çocuklar ise yetişkinlerin karşılaştığı yoksulluk ve beraberinde işsizlik ile işgücüne katılmaktadır. Formel sektörde iş imkânı bulamayan yetişkinler kendilerine ve çocuklarına enformel sektörde iş bulmaya çalışmaktadır. Bilgi, teknoloji ve çalışanların örgütlenme düzeyi ile çalışma standartları düşük olan enformel sektörün genişlemesi, kentlerde de çocuk işgücüne talebi arttırmaktadır. Geleneksel değerler, sağlık, güvenlik ve eğitim hizmetlerinden yoksunluk, çalışma standartlarının denetlenmesindeki eksikler gibi nedenlerle işyerlerinde çalıştırılan çocuklar istismara ve ihmale uğramaktadır (Zeytinoğlu, 2001: 85-86).

Modern çağda çocuk istismar sorununun hemen her ülkede başat bir sorun olmasıyla, sokaklar çocuklar için her zamankinden daha fazla riskli bir konuma gelmiştir. Son y1llarda Türkiye'de de sokaklar, çocuklar için oyun ve sosyalleşme alanlarından çıkıp yerini çocuk kaçırma olayları, çocuk tacizleri ve tecavüzleri gibi sorunlara bırakmıştır. Ebeveynler, yaşanan sorunlar karşısında çocuklarını sokaktan uzak tutan eğilimleri pekiştirmiştir. Sokakta çalışan çocukların sokaktaki çalışma sürelerinin uzun olması ve alt-kültürü temsil eden kişilerle sıklıkla karşılaşmaları, çocukların fiziksel veya cinsel yönden sömürüye maruz kalma risklerini arttırmaktadır (Bilgin, 2012: 81-82, 85).

Ak Parti hükümetleri döneminde önemle ele alınan bu olumsuz tablo özellikle Aile ve Sosyal Politikalar Bakanlığı'nın kurulmasıyla olumlu bir gelişme göstermiş olmakla birlikte, 2011'den bu yana beş yıldır süren Suriye iç savaş1 sebebiyle ülkemize yönelen üç milyonu aşkın mülteci akınının büyük oranda 
çocuklardan oluşması soruna yeni bir boyut kazandırmıştır. 04.04.2013 Tarih ve 6458 Sayılı Kanun'un 103. Maddesi çerçevesinde kurulan Göç İdaresi Genel Müdürlügü̈'nün tüm il ve ilçelerde teşkilatlanmasının ve mültecilere yönelik hizmetleri AFAD'dan devralmasının gecikmesi, mülteci sokak çocuklarının ortaya çıkmasına yol açmış olup bu husus ayrı bir çalışmada incelenmelidir.

Çocuklar, sokakta bedensel veya fiziksel kalıcı hasara maruz kalabilmelerinin yanında psikolojik ve sosyal yönden de sokakların taşıdığı risklerden önemli ölçüde etkilenebilmektedir. "Benlik kazanmada gecikme", "moral değerlerde düşüklük" ve "kişilik bozuklukları" gibi patolojik rahatsızlıklara yakalanma risklerinin oldukça yüksek olduğu belirtilmektedir (Alacahan, 2010: 143). Örneğin; çocukların sokaklarda karşılaştıkları bazı şiddet eylemleri onlarda travma yaşatabilecek derecede tehlikeli düzeye ulaşabilmekte ve çocuğun maruz kaldığ 1 şiddet eylemleri onları da aynı şekilde şiddet uygulayabilecek bireylere dönüştürebilmektedir (Kızmaz ve Bilgin, 2010: 305). Yaşadıkları şiddetin etkisiyle “şiddetin çocukları" olabilmektedirler (Bilgin, 2012: 83).

Keskinkılıç Kara ve Çalık'ın (2012: 682), ilköğretim okuluna devam eden ve sokakta çalışan çocukların eğitim ihtiyaçlarının belirlenmesini amaçlayan araştırmasında sokakta çalıştırılan çocuklar (\%87,21 ile) sokaktaki çetelerden ve diğer insanlardan tepki ve şiddet gördüklerini belirtmişlerdir. Çocukların karşılaştıkları tepki türünün ise $\% 45,33$ ile sözlü şiddet ve \%22,36 ile fiziksel şiddet olduğu görülmektedir.

Sokakta çalıştırılan çocukların bir bölümü kazançlarının tümünü ailelerine verirken bir bölümü de elde ettikleri kazancı kendilerine ayırmaktadır. Çocukların zamanla ailelerine verdikleri payı azaltıp kendi paylarını arttırmaları eğiliminde ise sokağın özgürlüğü ve kendi kendilerine yetebilirlik duygusu ile aileleriyle olan bağlarını koparmakta ve "sokağın çocuğu" "sokakta yaşayan çocuk" konumuna gelebilmektedir (Okumuş, 2009: 13-14).

Çocukların çalışırken aile denetiminden ve korumasından yoksun olmaları, güvenliklerini tehlikeye atmakta, bu tehlikeler de çeşitli risklere götürmektedir. $\mathrm{Bu}$ durum çocukların her çeşit sömürü ve istismara açık hale gelmelerine sebep olmaktadır. Aile denetiminden uzak kalan çocuklar olumsuz şartlar altında çalışırken uçucu ya da uyuşturucu madde kullanma ve suça yönelme tehlikesi ile karşılaşmaktadır (Avşar ve Ögütoğulları, 2012: 15).

Çalışma mekânı olarak çocukların sokaklarda maruz kaldıkları riskleri ve tehlikeleri ortaya çıkarmayı amaçlayan araştırmada, sokakta çalıştırılan çocukların sigara, esrar, alkol, uçucu ve yapıştırıcı maddeler (tiner-bali), çeşitli haplar (ecstasy, rohypnol, rivotrilklonezepam) gibi bağımlılık yapıcı maddeleri kullandığı tespit edilmiştir. Çocuklar, bu maddeleri bulamadıkları zaman ise çeşitli ağaç ve bitki yapraklarını sigara şeklinde sararak içtiğini dile getirmişlerdir. Bununla birlikte sokakta çalıştırılan 400 çocuğun \%65.5'inin, sigara dâhil bağımlılık yapıcı madde kullanan arkadaşa sahip olduğu görülmektedir. Sigara dışında kullanılan bazı maddelerin illegal nitelik taşıması, çocukların suça sürüklenmelerine de neden olmaktadır (Bilgin, 2012: 90). Bu bağlamda, madde kullanımına başlanmasında etkili olan akran grubunun sokakta çalıştırılan çocuklar üzerinde de etkili bir kitle olduğu belirtilebilir. Madde kullanımı, çocuğa bedenen ve ruhen zarar vermekte ve 
çocuğun bu maddeye ulaşmada kullandığı yöntemlerle de illegal eylemlerde bulunarak çevresine zarar vermektedir.

Sokakta çalışan çocukların özellikle sokaktaki risk ve tehlikelere açık bireyler konumunda bulundukları için suça eğilimli hale geldiklerini söylemek gerekir. Sokaktaki sapkın bireylerle ya da akranlarla temas etme yoğunluğu ve suçlu kültürlerle temas etme imkânı, okul ve aile bağlılığının zayıflaması, ebeveynleri ile olan ilişkilerin zayıflaması veya ebeveyn denetiminden yoksun olma (gerekli ilgi ve sevgiyi görememe) gibi unsurların sokakta bulunan çocukların suça itilmelerine sebebiyet verebilmektedir. Çalışılan sokak ortamının niteliği, çocukların suça yönelik motivasyona sahip olabilme risklerini arttırmaktadır. Sosyo-ekonomik sorunlar, aile desteğinden mahrum kalmaları ve çocukların sahipsiz-kimsesiz konumda bulunmaları sokakta çalıştırılan çocukların suç işlemesi açısından potansiyel bir grup oluşturmaktadır. Örneğin; kimsesiz çocuklar temel ihtiyaçlarını karşılayabilmeleri açısından yasal olmayan hırsızlık, yankesicilik, madde kullanımı ve satışı, gasp, yaralama gibi bazı suçlara karışabilmektedir. Bununla birlikte çocuk yetiştirme konusunda bilinçsiz olan bazı ebeveynler çocuklarını zorla çalıştırmakta ve daha fazla kazanç sağlamaları için çocuklarını zorlamaktadırlar. Zorla çalışmak zorunda bırakılan çocukların istenilen düzeyde para kazanamadıkları ve kazandıkları parayı kişisel harcamalarında kullandıklarında akşam veya gece eve dönme konusunda isteksiz olup bazen de eve dönmedikleri belirtilmektedir. Ebeveyn baskısına maruz kalan çocuklar şiddet, hakaret, hırpalama, ilgisizlik gibi tutumlara da maruz bırakılmakta ve bu tutum çocukların ebeveynlerine karşı duydukları ilgi ve bağl11ıkları zayıflatmaktadır (Kızmaz ve Bilgin, 2010: 273-276).

Bilgin'in $(2012: 88,92)$ araştırmasında sokakta çalışan çocuklar; hırsızlık, kapkaç, yankesicilik, illegal madde satmayla ilişkili çeşitli suç örgütlerinde yer aldıklarını dile getirmişlerdir. Terör örgütlerinin gerçekleştirdiği illegal sokak eylemlerini de sokakta çalıştırılan çocuklar için bir risk unsuru olarak değerlendirmenin yanında kimi zaman sokak hareketlerinde yer aldıkları çocuklar tarafından ifade edilmiştir. Bununla birlikte, çocuklar çalışma ortamında kazalara maruz kaldığı için bedenlerinde izlere ve yaralara sahip olmaktadırlar. Çocukların bir kısmının ise ciltlerinin canlılığını yitirdiği, soluk bir halde olduğu ve çocukların maruz kaldıkları yaralanmalar, çizikler/kırıklar için bilgisizlik ve yoksulluk nedeniyle çoğunlukla tedavi edilmediği de bu araştırma kapsamında görülmüştür.

Çocuklar sıklıkla trafiğin yoğun olduğu ortamlarda çalıştıkları için trafik kazalarına daha çok maruz kalabilmektedir. Örneğin; trafik akışının yoğun olduğu yol kenarlarında dilencilik yapma, cam silme, mendil, çiçek, su ve çekirdek vb. ürünleri satmak için koşuşturmaları onları daha kolay kazaya maruz bırakabilmektedir. Özellikle trafik 1şıklarının olduğu yerlerdeki çocukların çoğunun birden fazla kaza geçirdiği veya kaza riski atlattığı düşünüldügünde, bu çocuk grubu için kazalara maruz kalmak yadırganan bir durum olarak görülmemektedir (Bilgin, 2012: 93).

Çöp toplama işi ise sokaklarda çocuklar tarafından yapılan niteliksiz işlerden biridir. Aynı zamanda çöp toplama işi, çalışma saatleri açısından da oldukça riskli olarak nitelendirilebilir. Çöpler genelde akşam/gece vakitleri veya karanlık çökmeye başladıktan sonra toplanmaktadır. Bu işi yapan çocuklar, saldırı ve şiddete maruz kalabilme riskleri içinde bulunmaktadır (Kızmaz ve Bilgin, 2010: 299-300). 
Yoksulluk ve düzensiz aile ilişkileri nedeniyle dışlanan çocuklar, toplumun olumsuz tutum ve tepkileriyle ikinci bir dışlamaya sokakta maruz kalmaktadır. Toplumun dışlayıcı ve damgalayıcı davranışları çocukların olumsuz kimliklerle kendilerini özdeşleştirmelerine neden olmaktadır. Bu sebeple çocukların sokak kültürünü içselleştirerek sokağın zorluklarına karşı ortak bir hayat tarzı geliştirmekte ve çocukların kendi aralarında geliştirdiği enformel kültürün kuşkusuz çok olumsuz sonuçları bulunmaktadır (Yıldız, 2007a: 67).

Çocuğun sokakta çalıştırılması ile çocuğun belirli bir işyerinde çalıştırılması durumları arasında niteliksel olarak algı farklılıkları vardır. Çocuğun belli bir işyerinde çalıştırılması, zanaatçılığ (usta-çırak ilişkisini) çağrıştırmakta ve toplumda eğitim görememenin alternatifi esnaflık/zanaatkârlık olarak görüldügünden, meslek öğrenmeleri amacıyla çocukların esnafların yanına yerleştirilmeleri olumlu karşılanabilmektedir. Çocuğun sokakta çalıştırılması ise küçük çapta ticaret deneyimi kazandırıyor olsa da marjinal işler olarak ifade edilmektedir. Sokaklarda mesleği öğreten kişilerin olmaması, geniş bir mekân olması nedeniyle tehlikelere açık olması, çalışma esnasında çocuğun denetlenmemesi sokakta çalıştırılan çocukların olumsuz algılanmasına neden olmaktadır. Genellikle toplumda kentlileşmemiş kesim çocuğun sokakta çalıştırılmasını yoksulluk/ekonomik yoksunluk gibi nedenlere bağlamakta ve bu kesim tarafindan çalıştırılan çocuklara "acımakta" ve "üzülmekte"dir. Kentlileşmiş kesim ise çocuğun ailesini suçlayarak aileyi etiketlemekte, kızmakta ve önemsememekle birlikte çocuğu ve aileyi ötekileştirmektedir (Yetim ve Çağlayandereli, 2007: 48, 54).

Eğitim düzeyinin yetersizliği, çocuk sorumluluğunun ebeveynler tarafından tam olarak algılanamayışına neden olmaktadır. $\mathrm{Bu}$ durumda çocuğun çalıştırılmasında yaşanan veya yaşanacak tehlikeler tahmin edilememekte veya algılanamamaktadır (Fidan, 2004: 33-34). Alacahan'ın (2010: 143) yaptı̆̆ 1 çalışmada ebeveynler, sokakta çalışan çocuğunun can güvenliği vb. tehlike içinde olduğuna inandıkları (\%75 ile), çocuğu için herhangi bir tehlike bulunmadığına (\%15 ile) inanırken, kalan kesim ise böyle bir tehlikeli durumunu hiç düşünmedikleri ve bunun akıllarına gelmediğini (\%10 ile) belirtmişlerdir. Bununla birlikte ebeveynler, çocuğun sokakta çalışması esnasında kötü alışkanlık edinme riskinin olduğunu kabul etmekte (\%60 ile), riskin bulunmadığını (\%25 ile) ve bir kısım ise böyle bir olumsuzluk olabileceğini düşünemediklerini (\%15 ile) ifade etmektedir. $\mathrm{Bu}$ sonuçlar doğrultusunda, ebeveynlerin farkındalığı, farkında olmayışı ya da farkında olmamayı tercihinden kaynaklı olarak çocuklarının sokaklarda yaşadığı ya da yaşayacağı riskleri ve tehlikeleri kabul etmiş görünmektedir. Sokakta çalıştırılan çocuklar sorununun sadece ekonomik yetersizlik veya aile bütçesine sağlanan katkı için olmadığını aynı zamanda ailelerin yaşadığı bilinçsizlikten kaynaklandığı sonucunu ortaya çıkmaktadır.

Eğitimle elde etmeyi düşündüğü sosyal statü ve meslek beklentisi ile çalışma zorunluluğu arasında yaşadığı çelişki çocukları kararsızlığa ve umutsuzluğa sürüklemektedir. Bir tercih yapma durumunda kalan çocuk, eğitimi terk edebileceği gibi, ailesine ve içinde bulunduğu şartlara karşı isyan duygusuyla olumsuz davranışlar sergileyebilmektedir (Alacahan, 2010: 138). Bununla birlikte eğitim görmesi gereken çocukların sokaklarda çalışmak zorunda kalması; erken yaşlarda edinmesi gereken bilgi, beceri ve tutumları edinememesine, ailelerinden aldıkları yoksulluğu devam ettirmelerine (Keskinkılıç Kara ve Çalık, 2012: 676-677) ve 
yetişkinlik dönemine gelindiğinde çocukların herhangi bir donanıma sahip olmayan düşük gelirli vasıfsız işgücünde yer almasına neden olmaktadır (Tor, 2010: 33).

Beguele ve Myers'a (1998: 7-8) göre çocukların çalıştırılması, psikolojik ve eğitsel açıdan şu sonuçları ortaya çıkarmaktadır:

Tablo 2: Çocukların Çalıştırılmasının Psikolojik ve Eğitsel Sonuçları

\begin{tabular}{|l|l|}
\hline \multicolumn{1}{|c|}{ Psikolojik Sonuçlar } & \multicolumn{1}{c|}{ Eğitsel Sonuçlar } \\
\hline $\begin{array}{l}\text { Çocukların zihinsel gelişimleri } \\
\text { zayıflamaktadır. }\end{array}$ & $\begin{array}{l}\text { Çocuğun, okula gitmeye firsat } \\
\text { birakmayacak kadar çok zamanını } \\
\text { almaktadır. }\end{array}$ \\
\hline $\begin{array}{l}\text { Çocuklar, yetişkinlik dönemine geldiğinde } \\
\text { hayallerini gerçekleştirebilmek için } \\
\text { gereksinim duyduğu temel becerileri } \\
\text { geliştirme şansının yok olmasına neden } \\
\text { olduğu görülmektedir. }\end{array}$ & $\begin{array}{l}\text { Okula devam etmesinde ve derse } \\
\text { etkin bir şekilde katılmasında gerekli } \\
\text { enerjiye sahip olamamaktadır. }\end{array}$ \\
\hline $\begin{array}{l}\text { İşyerinde kötü muamele gören çocuklar, } \\
\text { derslere dikkatini verememekte, } \\
\text { öğretmenler tarafından, diğer öğrencileri } \\
\text { engellediği gerekçesiyle okuldan } \\
\text { uzaklaştırılmaktadır. }\end{array}$ & $\begin{array}{l}\text { Özellikle mevsimlik işlerde, çalışma } \\
\text { zamanının uzunluğundan, çocuk } \\
\text { okula kayıt olsa dahi derslerine } \\
\text { çoğuna devam edememektedir. }\end{array}$ \\
\hline $\begin{array}{l}\text { İşin sikıcılığı, itibarsızlığı, aile bağının } \\
\text { kopuşu, çocuğun oyun oynamasına ve diğer } \\
\text { çocuklarla arkadaşlık etmesinde firsat } \\
\text { vermeyecek derecede işin zaman alması, } \\
\text { çocuğa psikolojik yönden zarar } \\
\text { vermektedir. Bununla birlikte değersizlik } \\
\text { duygusu, kayıtsılık ve soğukluk duygusu } \\
\text { oluşabilmektedir. }\end{array}$ & $\begin{array}{l}\text { Genelde sokakta çalıştırılan } \\
\text { çocuklarda, sokakta bulunduğu } \\
\text { ortamın tesiriyle öğrenime verilen } \\
\text { değer azalmaktadır. }\end{array}$ \\
\hline
\end{tabular}

(Bilgiler, Bequele ve Myers'in (1998) çalışmasından alınmış olup tarafımızca tablo haline getirilmiştir.)

\section{Eğitim, Çocuk Hakları ve Uygulama Stratejileri}

Sokakta çalıştırılan çocuklar; "Çalışma nedenleri ve kendilerine verilen ad ne olursa olsun, zorunlu eğitim çağında, rüsst yaşını tamamlayamadan, kendilerini çalışma yaşamının zor ve tehlikeli koşullarında bulan çocuk ve gençler hukuki korumadan, sunulan çeşitli hizmetlerden ayrıcalıklı ve ağırlıklı olarak yararlanması gereken hedef kitleyi oluşturmaktadır." (Karabulut, 1996: 6).

Sokak Çalıştayı'nda (2012), sorun alanına ilişkin okulda ve çevresindeki olumsuz ilişkilerden çocukların korunmasını sağlayan, ilişkileri yapılandıran mesleğin sosyal hizmet mesleği olması gerekliliğinden, okul sosyal hizmet alanının öneminden, çocuğun ve ailenin iyi tanımlanması gerektiğinden, kurumsal işbirliğinin olmamasından, kurumların eşit paydaşlar olduğundan, ortak sorumluluklarının uygulama içinde olması gerektiğinden, eşgüdümlü politikaların ve uygulamaların izlenmesinin öneminden, uygulamalarda politik iradenin olmas1 gerektiğinden aksi takdirde hizmetlerin yürütülemediğinden, kurumsallaşmış 
hizmetin yoksunluğundan, kurumsal bir hizmetin sağlanması gerekliliğinden, sokak çocukları sorununun diğer bütün sosyal sorunlarla ilişkili olduğundan, bütüncül yaklaşılması gerektiğinden ve çocukların boş zamanlarını değerlendirmesi için etkinlikler düzenlenmesi gerektiğinden, bu etkinlikleri düzenleyen bütüncül merkezlerin olması gerekliliğinden bahsedilmektedir. Bununla birlikte vaka yönetiminin, sosyal hizmetin en önemli araçlarından biri olduğu belirtilmektedir. Bir vakayı çözümlerken sosyal çevresiyle birlikte değerlendirmenin önemli olduğu vurgusu yapılmaktadır. Vaka yönetiminin personel yetersizliği, çalışan çocukların sayısının fazlalığı gibi birtakım engellerden dolayı gerçekleşemediğinden bahsedilmekle birlikte asıl sorun, sokakta çalışan çocuklar sorununun çözülmesinin mümkün olmadığı yönünde kanaatlerin ifade edilmesidir. Ailelerle birebir ilgilenilmesi gerektiğinden, bunların her birini birer vaka olarak değerlendirip aylarca ilgilenilmesiyle sorunların kalıcı olarak çözülebileceğinden bahsedilmektedir.

Sosyal Hizmet Uzmanları Federasyonu'nun 1957'de yapmış olduğu küresel tanıma bakıldığında;

"Sosyal hizmet bireylere ve gruplara, topluma daha iyi adaptasyonları için yardım etmenin sistematik yoludur. Sosyal hizmet uzmanı, iç kaynaklarını geliştirmeleri ve mobilize olmaları için müracaatçılarla birlikte çalışır, gerekirse, çevrede değişim sağlamak için dış kaynaklardan da destek alır. Şöyle ki, sosyal hizmet toplumdaki harmoniye katkı sağlamaya çalışır. Diğer mesleklerde olduğu gibi sosyal hizmet özelleşmiş bilgiye, kesin prensiplere ve becerilere dayanmaktadır." (ifsw.org, 2016).

Bu tanımdan hareketle, sosyal çalışmacılar; ailelerin ve çocukların toplumda var olan hizmetlerden yararlanması için "arabuluculuk" yapar. Sorunların çözümüne yönelik politikaların oluşturulmasında, hak ihlallerinin ve adaletsizliğin önlenmesinde "savunuculuk" yapar. Bununla birlikte, var olan kaynakların kullanımı, kaynaklara yönlendirme ile ilgili olarak diğer meslek elemanlarıyla işbirliği içinde hareket ederek, çalıştırılan çocukların ve ailelerinin yaşadığ sorunlara yönelik "danışmanlık" yapar. Ayrıca politika ve stratejilerin geliştirilmesine yardımcı olabilecek verileri toplar, analiz eder ve sonuçlarını ilgili kurum ve kuruluşlara aktarır.

Genelci sosyal hizmet yaklaşımı, sorunu bütüncül bir bakış açısı içinde ele almakta ve sadece bir sorun üzerine odaklanmanın ötesinde sorunun etkileşim içerisinde olduğu diğer sistemleri ve bu sistemlerin birbiriyle olan ilişkileri üzerine odaklanmaktadır (Yolcuoğlu, 2010: 80). Çocukların sokakta çalıştırılma nedenlerini görebilmek için; var olan sosyal, ekonomik, kültürel ve psikolojik boyutlarının bir arada değerlendirilmesi gerekmektedir. Sadece çalıştırılan, emeği sömürülen çocukların araştırılması kapsamlı bir analiz için yeterli değildir. Aile, çevresel ilişkiler ve toplum üçgeni içerisinde var olan sorunun nitelendirilmesi kalıcı çözümlerin üretilmesi için gereklidir.

Çocuk sokaklara tercihen değil mecburen yönelmekte ve bu yönelişte sosyoekonomik şartlar etkili olmaktadır. Bu nedenle çocuğun içinde bulunduğu sistemin yapısının iyi tanımlanması gerekmektedir. Başta aile ve ilişkide bulunduğu diğer kişiler ile toplum yapısının da bu sistem içine dâhil edilip değerlendirme yapılması 
gerekmektedir. Kısaca, sorunun odağını çalıştırılan çocuk oluşturmamaktadır. Çocuğu çalışmaya iten sistem aile, çevre, çocukla ilişkisi olan diğer kişi/kişiler vb. unsurlar oluşturmaktadır. Bununla birlikte, bir işletmede iş güvenliği daha kolay sağlanabilirken ya da çocuk işyerinde gözlem altında tutulabilirken, bu durum sokaklar için çok daha zor olmaktadır. Sokakta çalıştırılan çocukların çalışma şartları ve karşılaştıkları/karşlaşabilecekleri risklere ve tehlikelere yönelik koruyucuönleyici çalışmaların yapılmasına ihtiyaç bulunmaktadır.

Sokakta çalıştırılan çocuklar sorunu; genelinde hakların ihlali ve hakların pratikteki eksikliği ve bunun sonucunda eğitim hakkının ihlaliyle sonuçlanmaktadır. $\mathrm{Bu}$ durumun yansımalarını ise uygulama ve müdahalelerde mevcut stratejilerin yetersizliğinden kaynaklanmaktadır: İşte bu bağlamda sokakta çalıştırılan çocuklar sorunu; haklar, eğitim ve uygulama stratejileri bağlamında irdelenmiştir.

\subsection{Eğitim}

Sokakta çalıştırılan çocukların, sokaktan kurtulabilmelerini sağlayacak önemli araçlardan biri eğitimdir. Sosyal çalışmacılar, eğitim sistemini güçlendirebilmek için çocukların genel durumları, sorunları ve okulda çocukların ne tür sınırlarla karşılaşıldığına ilişkin araştırmalar yapmalıdır. Bunun için mesleki iş birliği önemlidir. Okul çalışan öğretmenlerle ve okul yönetimiyle birlikte öğrencilerin sosyo-ekonomik durumuna ilişkin analizler yaparak çalıştırılması muhtemel olan çocuklara ve ailelerine yönelik erken müdahale programları geliştirilmelidir. Bu noktada okul sosyal hizmetinin öneminin farkına varmaktayız. Okullarda sosyal hizmet çalışmacılarının bulunması, ileride çocuğun yaşaması muhtemel sorun ve risklerin tespiti için önemli olmaktadır. Kısacası, eğitim alanına ilişkin sosyal hizmet mesleğini de bünyesine dâhil eden yapıların oluşturulması gerekmektedir. Eğitim hem bir araçtır hem de bir kaynaktır. Bu kaynağa erişemeyen çocukların erken yaşta iş hayatına atılmaları muhtemel gözükmektedir. Bununla birlikte eğitim, çocuk işçiliğinin farklı bir boyutunu oluşturmaktadır. Aile, çocuğunun eğitim masraflarını karşılayamaması sebebiyle çocuk okula devam edememektedir. Eğitimine devam etmediği için erken yaşta iş hayatına girip ileriki yaşlarda vasıfsız işçi olarak hayatına devam etmektedir.

Kenya'da, Undugu'da sokak çocuklarıyla yapılan çalışmalarda, çocukların şu konularda potansiyellerinin olduğu ortaya çıkmıştır (Dallape, 1988; akt. Ennew, 1998: 139):

- Öğrenme arzusu, ‘eğitim' alma hevesi

- Hayatta kalma bilgisi,

- Hayatın çilesini çekmiş olmanın, zorluklara göğüs germenin ya da uyum sağlamanın verdiği deneyim,

- Bireysel olarak ve grup halinde kendilerini örgütleme yeteneği,

- Grup içinde dayanışma ve arkadaşlık,

- Diğer yoksullarla dayanışma,

- Her tür işi yapma isteği,

- Hoşça vakit geçirmede yaratıc1lık. 
Var olan bu potansiyellerin ortaya çıkartılmasında hem çocuk, hem okul, hem de toplum yönüyle güçlendirilmesinde mobil okul (eğitim) hizmeti başarılı bir uygulama örneğidir.

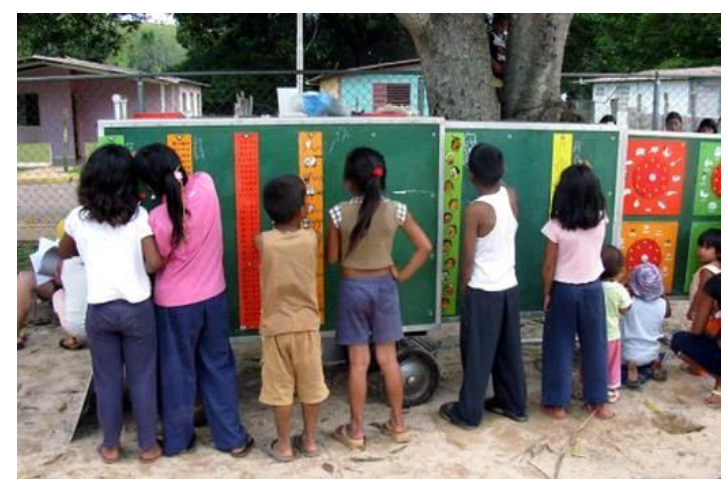

Kaynak: http://www.mobileschool.org/nl

Mobil okul, uzatılabilir tekerlekli tahtalarla sağlanan eğitim hizmetidir. Barındırdığı sistem ve tasarımı sayesinde kaldırımlara, meydanlara, parklara ve büyükşehrin gecekondu yerleşkelerine kurulabilmektedir. Yeteri kadar eğitici istihdam edilmektedir. Bununla birlikte okuryazarlık, yaratıcı terapi, sağlık eğitimi ve uyuşturucu-madde kullanımını önlemeye yönelik eğitimler verilmektedir (www.mobileschool.org, 2016). Bu uygulama; sokak çocuklarına, sokakta çalışanlara, okuldaki öğrencilere ve öğretmenlere yönelik olarak sunulmaktadır.

Mobil okul sosyal stratejisi çocukların güçlü yanlarını, yeteneklerini ve potansiyellerini ortaya çıararak becerileriyle birlikte çocuğun güven kazanmasını teşvik etmektedir. Böylece, çocuklar kendi hayatlarının temel aktörleri haline gelebilmektedir. Bununla birlikte olumlu ve yapıcı bir yardımla, sokakta çalıştırılan çocuk için güvenilir bir ortam oluşturulmasına ve kendini geliştirmesine katkı sağlamaktadır (www.mobileschool.org).

Çalıştırılan çocuklara yönelik sokaklarda sunulan eğitim, çocuklara özgüven aşılamaktadır. Çocukların sokakta çalışmasının ötesinde bir özeleştiri sağlayarak durumuna ilişkin değerlendirme ve geleceğe yönelik kendi seçimlerini yapmasına imkân sağlamaktadır (www.mobileschool.org). Bu doğrultuda ilk amaç çocuğun güçlendirilmesi iken uzun erimde çocuğun geleceğe yönelik seçim yapmasında (zorla çalıştırılmamasında ya da okula gitmesinde) imkân sağlamaya çalışmaktadır. 


\subsection{Cocuk Hakları}

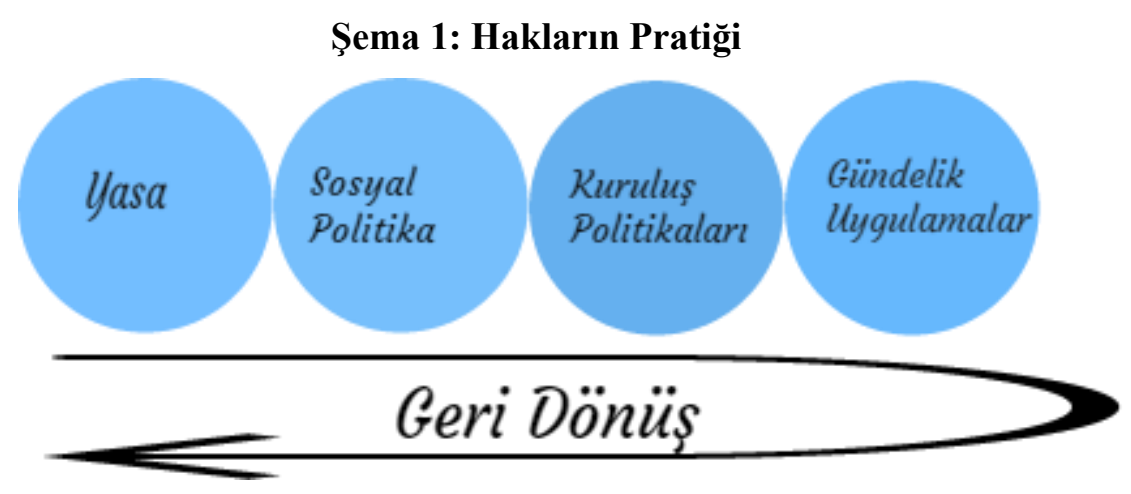

Ulusal ve uluslararası hukuki düzenlemelere rağmen, hakların sağlanması ve ihlallerden korunması açısından uygulamada yetersiz kalındığı görülmektedir. Çocuk haklarının gerçek hayatta pratiğe yansıması ve gerekli sosyal politikaların üretilmesi konusunda devletler geriden gelmektedir. "Şema 1: Hakların Pratiği " üzerinden hareketle yasalar, doğrudan haklar bağlamında sosyal politikaları etkilemeli ve üretilen sosyal politikalar aynı zamanda insani hizmet sunan kuruluş politikalarını ve genelinde toplumda hakların uygulanabilirliği açısından gündelik pratikleri doğrudan etkilemelidir.

Gündelik uygulamaların sisteme bir cevap olarak verdiği olumlu ve olumsuz geri dönüşlerine göre kuruluş politikası ve sosyal politika pratiği yeniden yapılandırılmalı, şayet mevcut ise engellerin ortadan kalkmasına yönelik yasal boyut gözden geçirilmelidir. Bununla birlikte insani hizmetler içinde sadece devlet ya da özel kuruluşları değil aynı zamanda geri dönüşlerde etkili olması beklenen hak ve özgürlüklerin savunuculuğunu yapan STK'lara da önemli sorumluluklar düşmektedir.

Çocukların katılımı da bu kapsamda düşünülmelidir. Türkiye'de seçme hakkı 18 yaşın bitimiyle başlamaktadır. Seçmen olmayan kitle olan çocukların görüşlerinin ve ihtiyaçlarının dikkate alınması, keza karar alma sürecine katılımlarının sağlanması gerekmektedir. Aksi takdirde çocukların katılımının göz ardı edilmesi tehdidi karşımıza çıkmaktadır (Özer, 2013: 254). Birleşmiş Milletler Çocuk Hakları Sözleşmesi'nin 12. Maddesi'nde sözleşmeye taraf devletler tarafindan çocuğun katılımı güvence altına alınmıştır. "Taraf Devletler, görüşlerini oluşturma yeteneğine sahip çocuğun kendini ilgilendiren her konuda görüşlerini serbestçe ifade etme hakkını, bu görüşlere çocuğun yaşı ve olgunluk derecesine uygun olarak, gereken özen gösterilmek suretiyle tanırlar." (http://www.unicef.org/turkey/crc/_cr23c.html, e.t. 20.06.2016).

\subsection{Uygulama Stratejileri}

Sosyal hizmet alanını, sistemci ve bütüncü yaklaşım oluşturmaktadır. Hem kuramsal hem de uygulamaya yönelik insan ve toplum odaklı sistemli ve bütüncül bir çalışma gerçekleştirebilmek için disiplinlerarası bir yaklaşım gerekmektedir (Cılga, 2004: 40). Sosyal hizmet mesleği hem çocuk, hem aile, hem de topluma 
yönelik müdahalelerde bulunan, bu yönde sosyal politika, proje ve stratejiler geliştiren, çözümleri alternatifiyle üreten, sorunu bütüncül bir yaklaşımla analiz eden bir meslektir.

Austin, (2002: 123-132) İnsani Hizmetler Yönetimi: Sosyal Hizmet Uygulamasında Örgütsel Liderlik adlı kitabında program stratejilerini altı alt başlıkta tanımlamaktadır. Bunlar; mesleki (profesyonel) strateji, sistem stratejisi, geçici servis (hizmet) stratejisi, sosyal bakım stratejisi, doğal bakım stratejisi ve toplum sağlığı stratejisi. Her insani hizmet sunan program, kendine özgü olarak program stratejileri geliştirmektedir. Geliştirilen program stratejisi, teknolojik gelişmelere, hizmetin sağlanma şekline ve teorik çerçeveye paralel olarak şekillenmektedir. Bununla birlikte program stratejileri birtakım sorumluluklar ve görevler yüklemektedir. Bunların başında meslek elemanına ve hizmet alan müracaatçılara (kullanıcı-yararlanan kimse) yönelik görev ve sorumluluklar gelmektedir. Bu sorumluluk ise profesyonel bilgi ve teknik beceri gerektiren hizmet alım süreci içerisinde de hesap verebilirlik ve kalite kontrolü gerektiren eylemleri barındırmaktadır. Sunulan hizmetler ise "yeterlilik (verimlilik)" üzerinden ziyade “etkililik" üzerinden değerlendirilmektedir.

Tablo 3: Uygulama Stratejileri, Eylemler ve Mesleki Roller

\begin{tabular}{|l|l|l|}
\hline \multicolumn{1}{|c|}{$\begin{array}{c}\text { Uygulama } \\
\text { Stratejileri }\end{array}$} & \multicolumn{1}{c|}{ Eylemler } & \multicolumn{1}{c|}{ Mesleki Roller } \\
\hline $\begin{array}{l}\text { Mesleki } \\
\text { (Profesyonel) Strateji }\end{array}$ & $\begin{array}{l}\text { Sokakta çalıştırılan } \\
\text { çocuklarla ve aileleriyle } \\
\text { birebir iletişim }\end{array}$ & $\begin{array}{l}\text { Görüşme, vaka analizi, } \\
\text { hizmet kayıtları (raporlar) }\end{array}$ \\
\hline Sistem Stratejisi & $\begin{array}{l}\text { Çocuk hakları ve çocuk } \\
\text { sorunlarına yönelik çalışan } \\
\text { örgütlerle iletişim }\end{array}$ & $\begin{array}{l}\text { Toplum düzeyinde çalışma } \\
\text { (makro), soruna ilişkin } \\
\text { disiplinlerarası } \\
\text { değerlendirme }\end{array}$ \\
\hline $\begin{array}{l}\text { Geçici Servis } \\
\text { Stratejisi }\end{array}$ & $\begin{array}{l}\text { Ailelere yönelik mesleki } \\
\text { eğitimler, çocuklara yönelik } \\
\text { kariyer planlamaları ve } \\
\text { okula devamında } \\
\text { oryantasyon sağlanması }\end{array}$ & $\begin{array}{l}\text { Eğitimlerin ve eğitime } \\
\text { ilişkin kaynakların } \\
\text { koordinasyonunu sağlama; } \\
\text { okul-aile-çocuk sisteminde } \\
\text { uygulama }\end{array}$ \\
\hline
\end{tabular}

(Bilgiler, Austin'in (2002) "Human Services Management Organizational Leadership İn Social Work Practice" kitabından alınmış olup tarafımızca tablo haline getirilmiştir.)

Burada sokakta çalıştırılan çocuklara yönelik, temel üç strateji değerlendirilmiştir (Tablo 3): mesleki strateji, sistem stratejisi ve geçici servis stratejisi. Mesleki (profesyonel) stratejinin oluşturulmasıyla sokakta çalıştırılan çocuklarla ve aileleriyle birebir görüşme sağlanıp ve bu görüşmeler sonunda görüşmelerin kayıtları (raporları) tutulmaktadır. Belirlenen sorunlara ilişkin mevcut kuruluş ve örgütlerle iletişim kurulup soruna ilişkin disiplinlerarası değerlendirilmeler yapılarak soruna yönelik çözümler alternatifiyle birlikte belirlenmektedir. Geçici servis stratejisinde ise ailelere ve çocuklara yönelik eğitim sağlanarak ailelerin işe yönelmelerine, çocukların ise okullara devamına yönelik kaynakların koordinasyonu sağlanmaktadır. Çocuğun okuldan uzaklaştığı süre 
içinde okula ve okuldaki eğitime uyumunun sağlanmasına yönelik oryantasyon eğitimleri verilmektedir.

Arap, Fars ve Slav dillerini konuşan komşu ülkelerde sokak çocuklarına yönelik çeșitli uygulama stratejileri uygulanmaktadır. Mesela, İran'da Sâzmân-1 Behziştî-i Kişver (Devlet Refah Kurumu) bünyesinde faaliyet yürüten ve nüfusu 200 bini aşan tüm yerleşim yerlerinde teşkilatlanan Sokak Çocukları Bakım Merkezleri, kendisinin veya ailesinin geçimi için çalışmak zorunda kalan veya sokakta yaşamak zorunda olan çocukları toplayarak, gerekli şartlar oluşup onları ailelerine teslim edene kadar bakımlarını ve eğitimlerini üstlenmektedir. İlgili diğer bakanlık, kurum ve sivil toplum kuruluşlarıyla da işbirliği yapan bu merkezler, çocukların yeteneklerini ortaya çıkararak onları kişiliklerine uygun yönde eğitime tabi tutmaktadır. Çocuklara temel eğitim imkânlarının sunulduğu bu merkezlerde sağlık, beslenme ve barınma gibi ihtiyaç duydukları tüm hizmetler; sosyal hizmet uzmanı, psikolog, psikiyatrist, pratisyen hekim, hemşire, avukat ve diğer personel tarafından sunulmaktadır (www.behzisti.ir, 2016). Ayrı bir çalışmanın konusu olan bu ülkeler karşılaştırması, sokakta çalıştırılan ya da sokakta yaşayan çocuklar için daha gelişmiş uygulama stratejilerinin geliştirilmesinde önemli bir katkı sağlayacaktır.

\section{Sonuç}

Araştırmanın sonucu olarak sokakta çalıştırılan çocukların emeğinin sömürülmesinde sadece ekonomik değil aynı zamanda ailesel ve çevresel faktörlerin etkili olduğu ifade edilebilir. Sadece gelire katkı sağlamak değil aynı zamanda ebeveynlerin çocuk yetiştirme bilincindeki yoksunluk ve eğitim seviyesinin düşük oluşu çocukların işgücüne katılmasına sebebiyet verebilmektedir. Bu gibi etkenler ve sorunlar bazı riskleri ve tehlikeleri beraberinde getirmektedir. Gerek sokağın kontrol edilmesinin güç oluşu, gerekse toplumun çocukları dışlamasından kaynaklanan etkiler sebebiyle çocuk kendisini sokak kimliği ile özdeşleştirmektedir. Dahası madde kullanımına başlayabilmekte veya suça sürüklenebilmekte ya da çeşitli illegal örgütlere katılarak yasadışı eylemlere yönelebilmektedir.

$\mathrm{Bu}$ doğrultuda sokakta çalıştırılan çocuklar sorununun çözümünde kullanılması gereken üç araçtan söz edilebilir: Eğitim, çocuk hakları ve uygulama stratejileri. Eğitim için alternatif modellerin geliştirilmesi gerekmektedir ki çalışmada ifade edilen mobil eğitim hizmetleri, yalnızca çalıştırılan çocuklara değil, aynı zamanda okul öğretmenlerine/ profesyonel meslek elemanlarına da uygulama stratejilerini belirleyebilmek amaciyla sunulmaktadır.

Aynı zamanda uygulama stratejileri kapsamında değerlendirmemiz gereken bir strateji türü de geçici servis stratejisidir. Çocuğun sokaktan uzaklaştırılması sağlanırken ailenin mevcut gelir düzeyi durumunu düzeltmek için ebeveynlerin iş/meslek edinmesinde ve çocukların okula dönmesinde ne tür bir geçici servis stratejisinin geliştirileceği temeli üzerinde şekillenmektedir. Bunun yanında mesleki uygulamaların, temel stratejilerin ve sunulan hizmetlerin çocuk hakları perspektifinden değerlendirilmesi ve çocuğa kendi haklarının korunmasında/ savunulmasında söz yetkisinin verilmesi, çocuğun toplumsal hayata kendisi için biçilen değer boyutu kadar değil kendi kendisine biçtiği değer boyutuyla katılmasının önü açılmalıdır. 
Kaynakça

Alacahan, Osman, (2010), "Çocuğunu Sokakta Çalıştıran Ailelerin Sosyo-Ekonomik Profili, Tutum ve Beklentileri”, İstanbul Üniversitesi Sosyal Siyaset Konferansları Dergisi, 59(2): 133-147.

Alparslan, Özgür, Bahattin KARAOĞLAN, (2012), "Sokakta Çalışan Çocukların Yaşam Koşulları”, Anadolu Hemşirelik ve Sağlık Bilimleri Dergisi, 15(4): 268-274.

Alptekin, Kamil, (2011), "Sokakta Çalışan Çocuklar ve Aileleri: Düzce Örneği", Hacettepe Üniversitesi Toplum ve Sosyal Hizmet Dergisi, 22(1): 25-48.

Austin, David M., (2002), Human Services Management Organizational Leadership in Social Work Practice, Columbia University Press, New York.

Avşar, Zakir, Eren Öğütoğulları, (2012), "Çocuk İş̧iliği ve Çocuk İş̧̧iliği İle Mücadele Stratejileri”, Sosyal Güvenlik Dergisi, 2(2): 9-40.

Baştaymaz, Tahir, (1990), 6-15 Yaş Grubu Bursa'da Çalışan Çocuklar Üzerine Bir Araştırma, Friedrich Elbert Vakfı Yayınları, İstanbul.

Bequele, Assefa ve William E.Myers, (1998), Çocuk İşçiliğinde Öncelikler: Çocuklar İçin Zararlı Olan İşlerde Çocuk Çalış̧ırılmasının Önlenmesi, Çev. Rasim Baykaldı, Çalışma ve Sosyal Güvenlik Bakanlığı, Ankara.

Bilgin, Rifat, (2012), "Sokakta Çallşan Çocukları Bekleyen Risk ve Tehlikeler: Diyarbakır Örneği”, ZKÜ Sosyal Bilimler Dergisi, 8(15): 79-96.

C1lga, İbrahim, (2004), Bilim ve Meslek Olarak Türkiye'de Sosyal Hizmet, Hacettepe Üniversitesi Sosyal Hizmetler Yüksekokulu, Ankara.

Ennew, Judith, (1998), Sokak Çocukları ve Çalışan Çocuklar: Planlama İçin Bir Rehber, Çev. Çiçek Özztek, UNICEF, Ankara.

Erder, Sema, Kuvvet Lordoğlu, (1993), Geleneksel Çıraklıktan Çocuk Emeğine Bir Alan Araştırması, Friedrich Ebert Vakfi, İstanbul.

Fidan, Fatma, (2004), "Çalışan Çocuk Olgusuna Sosyo-Psikolojik Bakış Sanayide Çalışan Çocuklar Örneği ", Trakya Üniversitesi Sosyal Bilimler Dergisi, 4(1): 30-49.

Genç, Yusuf, (2016), "Sokakta Yaşayanlar: Evsizler ve Sokak Çocukları”, Sokak Sosyal Hizmeti ve Adli Sosyal Hizmet, Ed. Hasan Hüseyin Taylan, Anadolu Üniversitesi Açıköğretim Fakültesi Yayınları.

Güneş, Sadık ve A. Rasim Kalaycı, (2004), Sokakta Yaşayan/Çalışan Çocuklar: Tespitler ve Çözüm Önerileri, Başbakanlık Aile ve Sosyal Araştırmalar Genel Müdürlüğü, http://ailetoplum.aile.gov.tr/data/5429366a369dc32358ee2a92/sokakta_y asayan_calisan_cocuklar_tespitler_ve_cozum_onerileri_10.doc, Erişim Tarihi: 20.06.2016. 
Yalova Sosyal Bilimler Dergisi

Güngör, Fethi, (2016), İnsan Hakları ve Sosyal Hizmet, İstanbul Üniversitesi Auzef. Yayını, İstanbul.

Günşen İçli, Tülin, (2009), Çocuk Suç ve Sokak: Sokakta Yaşayan Suç İşleyen ve Suça Maruz Kalan Çocuklar, Başbakanlık Aile ve Sosyal Araştırmalar Genel Müdürlüğü, Dumat Ofset Matbaa, Ankara.

Karabulut, Özcan, (1996), Türkiye'de Çalışan Çocuklar, Friedrich Ebert Vakfi Yayınları, İstanbul.

Karaman, Banu, Melih Özçalık, (2007), “Türkiye'de Gelir Dağılımı Eşitsizliğinin Bir Sonucu: Çocuk İsgücü”, Yönetim ve Ekonomi Dergisi, 14(1): 25-42.

Keskinkılıç Kara, Sultan Bilge, Temel Çalık, (2012), "Sokakta Çalışan Çocukların Eğitim Ihtiyaçları", Gazi Üniversitesi Gazi Eğitim Fakültesi Dergisi, 32(3): 673-695.

Kızmaz, Zahir, Rıfat Bilgin, (2010), "Sokakta Çalışan/Yaşayan Çocuklar ve Suç: Diyarbakır Örneği”, Elektronik Sosyal Bilimler Dergisi, 9(32): 269-311.

Köksal, Sema Erder, Kuvvet Lordoğlu, (1993), "Çıraklık ve Çocuk Emeği Araştırması”, Çalışma Ortamı Dergisi, Fişek Özel Sağlık Hizmetleri ve Araştırma Enstitüsü Yayını, http://calismaortami.fisek.org.tr/wpcontent/uploads/calisma_ortami8.pdf, Erişim Tarihi: 20.06.2016.

Okumuş, Ejder, (2009), “Sokak Çocukları'nın Sosyolojisi: Diyarbakır Örneği”, Din Bilimleri Akademik Araştırma Dergisi, 9(1): 9-37.

Özer, Y. Emre, (2013), "Çocuk Haklarl, Katılım ve Yerel Düzeyde Uygulaması: Türkiye Örneği”, C.Ü. İktisadi ve İdari Bilimler Dergisi, 14 (1): 245258.

Rodgers, Gerry, Guy Standing, (1981), "The economic roles Of Children: Issues for Analysis", Childwork, Poverty and Underdevelopment, Ed. Gerry Rodgers, Guy Standing, Ilo, Geneva.

Sokak Çocukları Çalıştayı, (2012), Güneydoğum Derneği, Ankara, Http://Www.Guneydogum.Org.Tr/İmages/Docs/Sokak_Cocuk.Pdf, Erişim Tarihi: 15.06.2016.

Şen, Bülent, Fatih Kahraman, (2012), "Oyun Hakkının Uzağında Yaşamak: Türkiye'de İ̧göç ve Çocuk Emeği”, Sdü Fen-Edebiyat Fakültesi Sosyal Bilimler Dergisi, S.27: 167-189.

Tor, Hacer, (2010), “Türkiye'de Çocuk Iş̧̧̧iliğinin Boyutları”, Zeitschriftfürdie Welt Der Türken Dergisi, 2 (2): 25-42.

Tunçcan, Nilgün, (2000), "Çocuk İşçiliği: Nedenleri, Boyutları ve Küreselleşen Dünyadaki Kопити”, Sosyal Siyaset Konferansları Dergisi, S.43-44: 243-259.

Vassaf, Gündüz, (2013), Cennetin Dibi: Modern Zamanlarda Eğlencelik Hayat, İletişim Yayınları, İstanbul.

Yetim, Nalan, Mustafa Çağlayandereli, (2007), "Toplumsal Algı Boyutuyla Sokakta Çalışan Çocuklar: Mersin Örneği”, Sosyoloji Dergisi, 3(14): 31-55. 
Yalova Sosyal Bilimler Dergisi

Yıldız, Özkan, (2007a), “Toplumsal Değişme Sürecinde Sokak Çocukları ve Sosyal Dışlanma”, Eğitim, Bilim ve Toplum Dergisi, 5(20): 56-72.

Yıldız, Özkan, (2007b), “Çalışan Çocuklar: 'Sorun' Mu? 'Çözüm' Mü?”, Gaziantep Üniversitesi Sosyal Bilimler Dergisi, 6(2): 134-143.

Yolcuoğlu, İ. Galip, (2010), "Çocukların İhmal-İstismara Ŭgramasında Aile ve Çocuklara Yönelik Risk Faktörleri ve Sosyal Hizmet Müdahalesi", Hacettepe Üniversitesi Toplum ve Sosyal Hizmet Dergisi, 21 (1): 7383.

Zeytinoğlu, Sezen, (2001), Çalışan Çocukların İstismarı ve İhmali, Ege Üniversitesi Basımevi, İzmir.

\section{Internet Kaynakları}

http://ifsw.org/sosyal-hizmet-nedir, Erişim Tarihi: 01.06.2016.

http://www.behzisti.ir, Erişim Tarihi: 01.09.2016.

http://www.mobileschool.org/en/solutions/empower-street-kids, Erişim Tarihi: 10.06.2016.

http://www.mobileschool.org/en/solutions/empower-street-workers, Erişim Tarihi:10.06.2016

http://www.mobileschool.org/nl/products/mobiele-school, Erişim Tarihi: 10.06.2016.

http://www.unicef.org/turkey/crc/_cr23c.html, Erişim Tarihi: 20.06.2016

http://cocukhizmetleri.aile.gov.tr/mevzuat/yonetmelikler, Erişim Tarihi: 25.06.2016.

http://www.ilo.org/ankara/conventions-ratified-by-turkey/WCMS_377311/lang-tr/index.htm, Erişim Tarihi: 20.06.2016.

http://www.ilo.org/ankara/about-us/WCMS_412372/lang--tr/index.htm, Erişim Tarihi: 20.06.2016. 